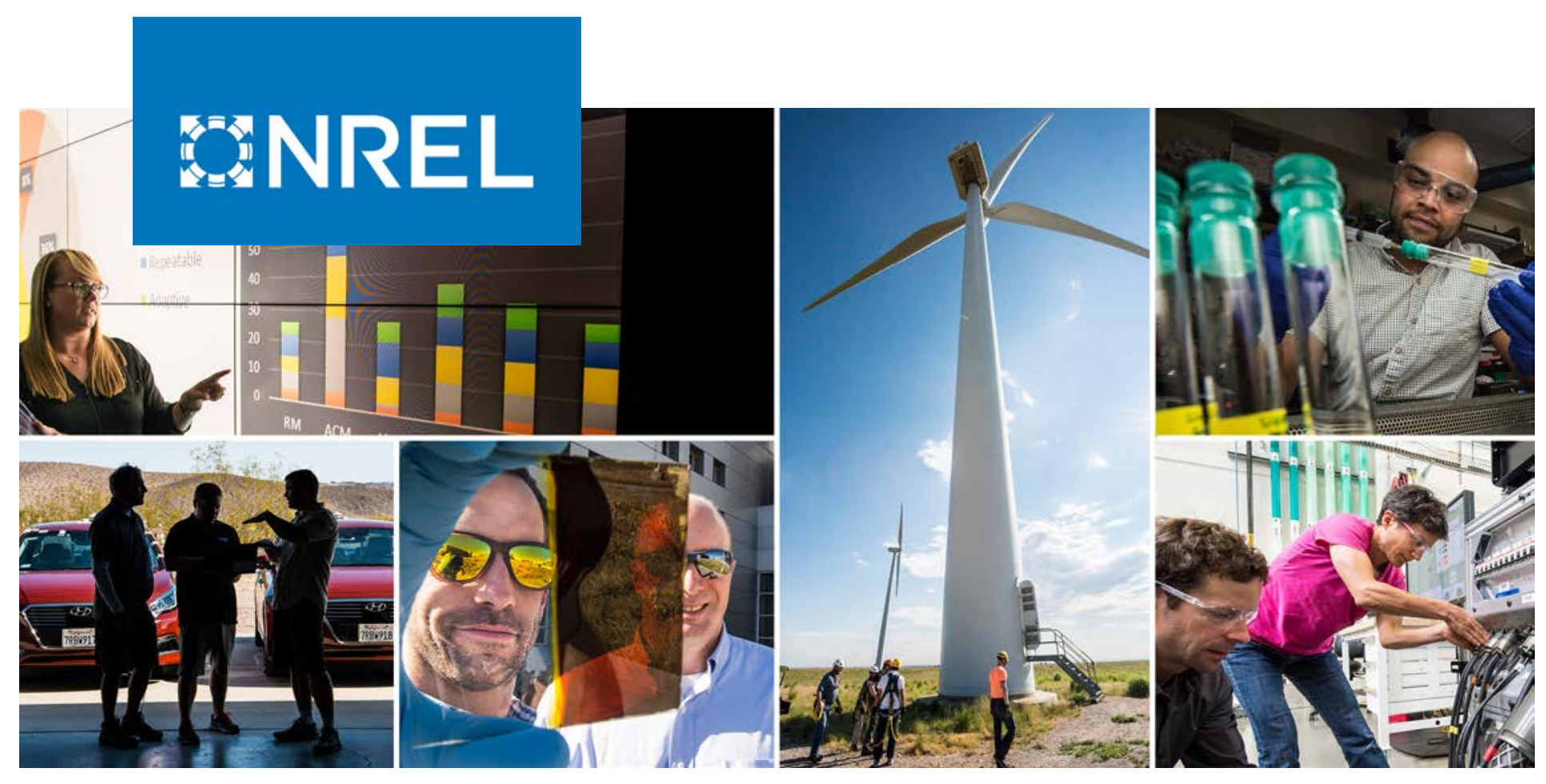

\title{
Testing and Evaluation of a Chemical- Free Cooling Tower Water Treatment Technology
}

Michael Deru and Eric Bonnema

National Renewable Energy Laboratory

NREL is a national laboratory of the U.S. Department of Energy

Office of Energy Efficiency \& Renewable Energy

Operated by the Alliance for Sustainable Energy, LLC

This report is available at no cost from the National Renewable Energy Laboratory (NREL) at www.nrel.gov/publications.

\section{Technical Report}

NREL/TP-5500-73911

August 2019 


\title{
GNREL
}

\section{Testing and Evaluation of a Chemical- Free Cooling Tower Water Treatment Technology}

\author{
Michael Deru and Eric Bonnema
}

National Renewable Energy Laboratory

\section{Suggested Citation}

Deru, Michael, and Eric Bonnema. 2019. Testing and Evaluation of a Chemical-Free Cooling Tower Water Treatment Technology. Golden, CO: National Renewable Energy Laboratory. NREL/TP-5500-73911. https://www.nrel.gov/docs/fy19osti/73911.pdf.

NREL is a national laboratory of the U.S. Department of Energy Office of Energy Efficiency \& Renewable Energy Operated by the Alliance for Sustainable Energy, LLC

This report is available at no cost from the National Renewable Energy Laboratory (NREL) at www.nrel.gov/publications.

Contract No. DE-AC36-08GO28308
Technical Report NREL/TP-5500-73911 August 2019

National Renewable Energy Laboratory 15013 Denver West Parkway Golden, CO 80401 303-275-3000 • www.nrel.gov 


\section{NOTICE}

This work was authored by the National Renewable Energy Laboratory, operated by Alliance for Sustainable Energy, LLC, for the U.S. Department of Energy (DOE) under Contract No. DE-AC36-08GO28308. Funding provided by the U.S. Department of Energy Office of Energy Efficiency and Renewable Energy Building Technologies Office. The views expressed herein do not necessarily represent the views of the DOE or the U.S. Government.

This report is available at no cost from the National Renewable Energy Laboratory (NREL) at www.nrel.gov/publications.

U.S. Department of Energy (DOE) reports produced after 1991 and a growing number of pre-1991 documents are available free via www.OSTI.gov.

Cover Photos by Dennis Schroeder: (clockwise, left to right) NREL 51934, NREL 45897, NREL 42160, NREL 45891, NREL 48097, NREL 46526.

NREL prints on paper that contains recycled content. 


\section{Acknowledgments}

The authors would like to thank Michael Boyko, George Chac, Terry Waldo, and Craig Banner of Dynamic Water Technologies; Maureen Erbeznik with the LA Better Buildings Challenge; Daniel Rodriguez, William Brady, Robert Gerhardstein, and Wally Ripalda from the City of Los Angeles; Mark Gentili from the Los Angeles Department of Water and Power; and Ali S. Rehan and Juful Moreno from Johnson Controls for their assistance in completing this research project. Michael Thuis from Colorado School of Mines was instrumental in the water quality analysis and in setting up the regression analysis for water savings, and Gregg Tomberlin and Ryan Morris from NREL performed a technical review of this report.

Finally, we appreciate the funding from the U.S. Department of Energy's High Impact Technology Catalyst program to complete this work. The U.S. Department of Energy's High Impact Technology Catalyst program enables federal and commercial building owners and operators to make sound investment decisions in next-generation building technologies based on their real-world performance.

Prepared for the U.S. Department of Energy by the National Renewable Energy Laboratory.

For more information, contact:

Michael Deru

National Renewable Energy Laboratory

Email: michael.deru@nrel.gov 


\section{List of Acronyms}

BAS building automation system

CV

CV(RMSE)

DWT

EIA

$\mathrm{kWh}$

LSI

NMBE

NREL

ORP

RMSE

RSI

UET

coefficient of variance

coefficient of variance of the root-mean-square error

Dynamic Water Technologies, LLC

U.S. Energy Information Administration

kilowatt-hour

Langelier Saturation Index

normalized mean biased error

National Renewable Energy Laboratory

oxidation reduction potential

root mean square error

Ryznar Stability Index

Universal Environmental Technologies 


\section{Executive Summary}

Cooling towers provide an effective method of heat rejection and are widely used for space conditioning, refrigeration, and industrial cooling applications. Maintaining cooling towers typically entails chemical treatments and regular blowdowns to control scale, corrosion, fouling, and biological growth. Typical water treatment processes result in $20 \%$ to $50 \%$ of the water consumption wasted as blowdown (based on cycles-of-concentration of 5 to 2). This document provides the results of a measurement and validation study of an alternative water treatment technology from Dynamic Water Technologies, LLC (DWT) and Universal Environmental Technologies (UET) that is chemical free and significantly reduces blowdown water requirements. The DWT-UET system consists of a reactor skid, small pump, small air compressor, and controller and is installed as a slip stream off the condenser water line to continually treat a small portion of the cooling tower water flow. The system uses electrolysis of the water in reactor cores to create a favorable environment for precipitation of the concentrated minerals and creates conditions that kill biological growth. The system maintains a dynamic balance of relatively high $\mathrm{pH}$ and $\mathrm{Ca}+$ ion concentration to minimize the potential for corrosion.

The DWT-UET technology was deployed on a cooling tower in a large office building in Los Angeles, California. The baseline performance and DWT system performances were monitored during the 2018 cooling season. A multivariable-linear regression model was developed to estimate annual water savings for 2018. The DWT-UET system saved an estimated $20 \%$ or 1.16 million gallons with a 5.5-year simple payback as shown in Table ES-1. The system also removed historical scale from the condenser tubes and cooling tower media. Removal of scale from the condenser tubes improves heat transfer and should improve the operating efficiency of the cooling system. Measurements taken in this project did not show changes in energy performance; however, the gradual scale removal and dynamic nature of the cooling plant operation make it difficult to measure changes in energy over the short duration of this study.

Table ES-1. Annual Performance Estimates for the DWT-UET System

\begin{tabular}{|l|r|}
\hline \multicolumn{1}{|c|}{ Term } & \multicolumn{1}{c|}{ Value } \\
\hline Annual water savings (gal) & $1,161,607$ \\
\hline Annual water savings (\%) & $20 \%$ \\
\hline Annual water and maintenance savings & $\$ 34,105$ \\
\hline Technology cost after rebates & $\$ 188,674$ \\
\hline Simple payback & 5.5 years \\
\hline $\begin{array}{l}\text { Net present value } \\
(15 \text { years, 2\% inflation, } 7 \% \text { discount rate) }\end{array}$ & $\$ 160,700$ \\
\hline
\end{tabular}




\section{Table of Contents}

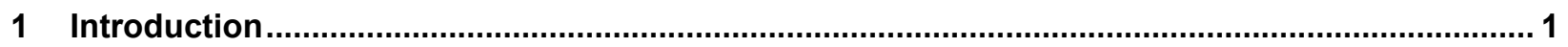

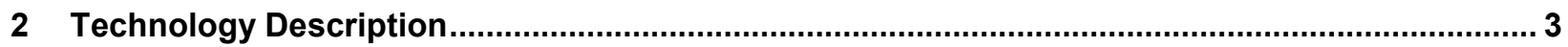

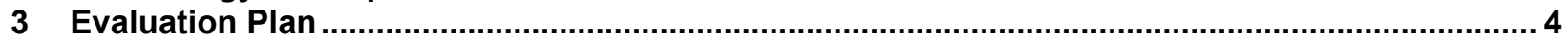

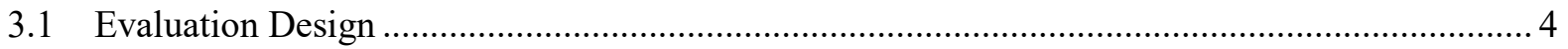

3.2 Test Site

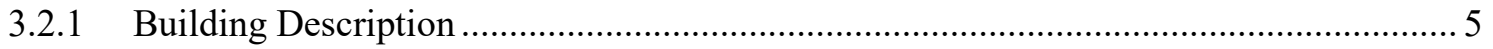

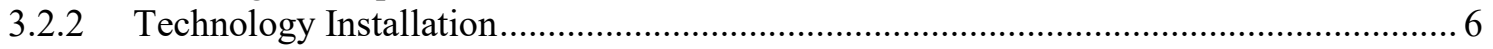



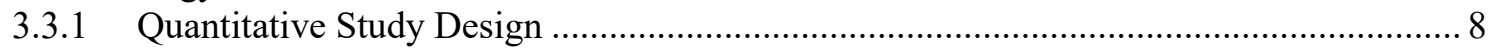



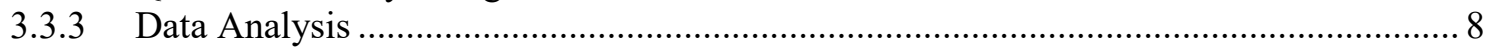







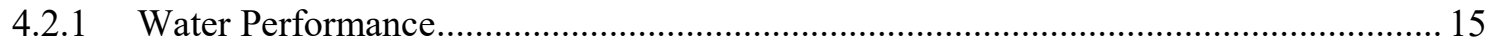

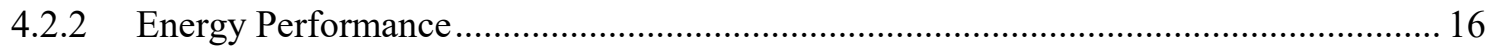

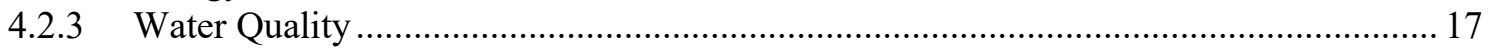

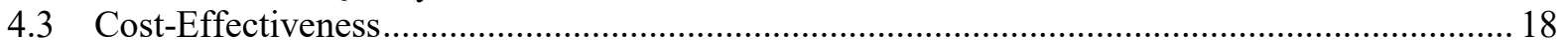





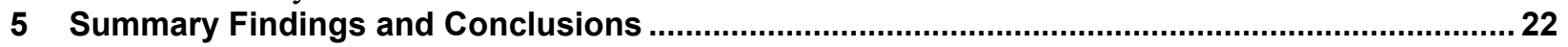

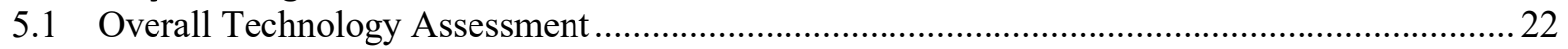

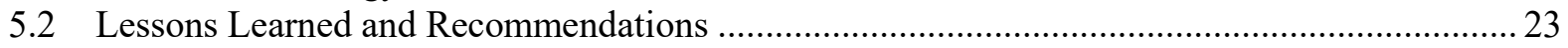

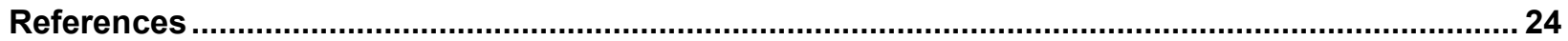



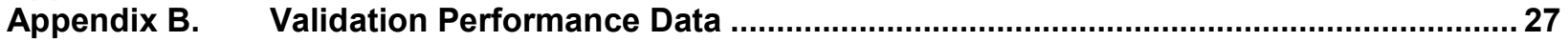



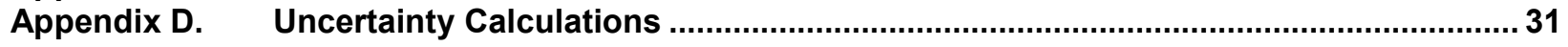




\section{List of Figures}

Figure 1. Water consumption by end use for commercial buildings ............................................ 1

Figure 2. UET system schematic …………………………................................................ 3

Figure 3. LA City Hall East with view of the cooling towers ........................................................ 6

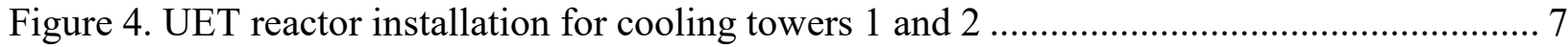

Figure 5. One of two UET reactor skid installations ............................................................. 7

Figure 6. Cooling tower basin water conductivity ................................................................. 14

Figure 7. Modeled daily water consumption from March 29 to December 31, 2018................... 15

Figure 8. Chiller plant load during similar baseline and DWT test periods ................................ 17

Figure 9. Chiller plant efficiency during similar baseline and DWT test periods ........................ 17

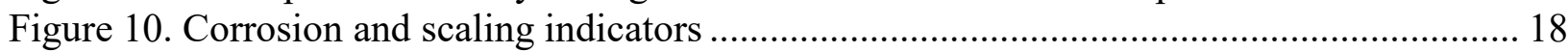

Figure 11. Reactor cores on October 26, 2018, and November 27, 2018 ................................ 20

Figure 12. Condenser tube borescope images at the beginning of and after 3 months of DWT-



\section{List of Tables}

Table ES-1. Annual Performance Estimates for the DWT-UET System .................................. V

Table 1. Quantitative Performance Metrics and Targets .................................................. 5

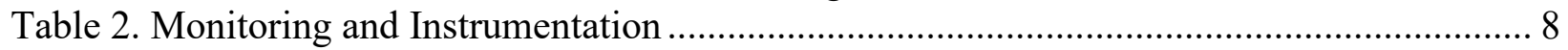

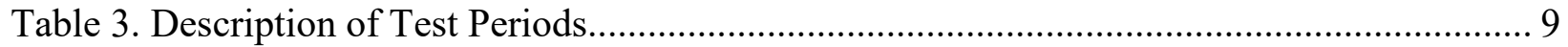

Table 4. Baseline Linear Model Coefficients and Associated Statistics ................................. 10

Table 5. Statistical Values of Baseline Model .................................................................. 10

Table 6. DWT-UET Linear Model Coefficients and Associated Statistics ............................... 11

Table 7. Statistical Values of DWT-UET Model................................................................... 11

Table 8. Cooling Load Linear Model Coefficients and Associated Statistics ........................... 12

Table 9. Statistical Values of Cooling Load Model............................................................ 13

Table 10. Estimated Annual Water Consumption and Savings for 2018 ............................... 16

Table 11. Estimated Annual Cost Analysis ......................................................................... 19

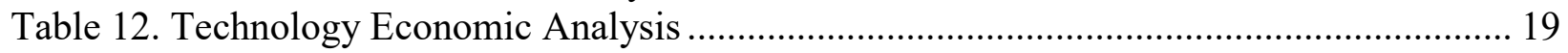

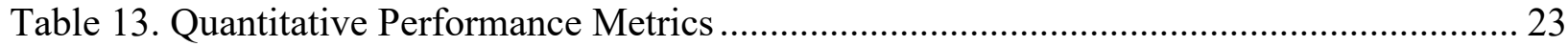

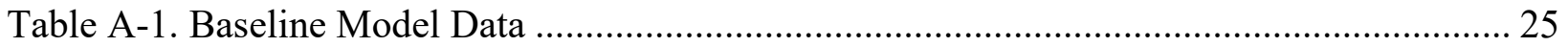

Table B-1. DWT-UET Model Data ..................................................................................... 27

Table C-1. DWT-UET System Acclimation Period Data...................................................... 30 


\section{Introduction}

Evaporative cooling is a very effective means for heat rejection and is used in many applications for commercial space conditioning, refrigeration systems, data centers, laboratories, and industrial systems. However, cooling towers and other evaporative cooling systems are a significant source of water consumption in the urban environment. In a typical office building with a water-cooled chiller, the cooling tower represents the largest water consuming end use. The U.S. Environmental Protection Agency estimates that $28 \%$ of the water use in office buildings is for the cooling and heating system.

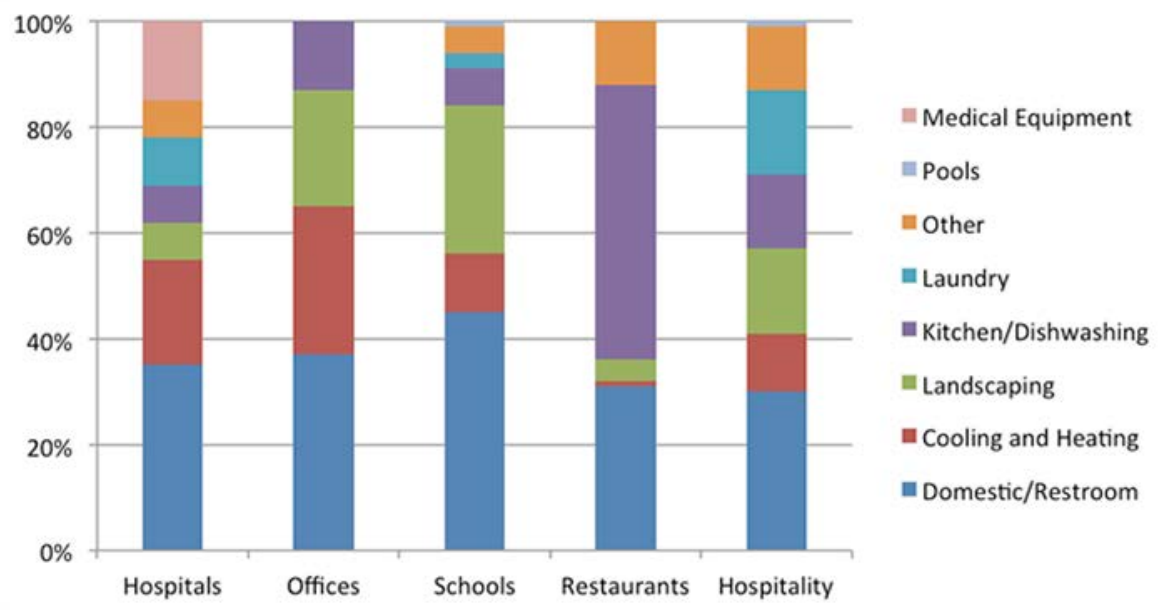

Source: U.S. Environmental Protection Agency (2017)

Figure 1. Water consumption by end use for commercial buildings

Central chillers (water cooled and air cooled) are used in over 200,000 commercial buildings representing more than 200 billion square feet of commercial building floor area (U.S. Energy Information Administration 2012). Cooling towers are often not optimally maintained and represent a substantial opportunity for water savings through utilization of best practice water treatment approaches. Maintaining the good water quality in evaporative systems involves managing scale, corrosion, fouling, and biological growth, while minimizing water consumption and total costs.

Evaporation of water leads to increased concentrations of the minerals naturally occurring in water. As the minerals become supersaturated, they preferentially precipitate on the hot surfaces such as the condenser tubes. Biological growth occurs in water systems in the right conditions of temperature, light, and friendly chemical conditions, which often exist in evaporative systems. Corrosion is driven by electro-chemical and biological factors that can be challenging to control. Maintaining the proper balanced water chemistry to control these three challenges can be difficult. Typical water treatment systems add antiprecipitant and dispersant chemicals to minimize scaling, acids to control $\mathrm{pH}$, corrosion inhibitors, and a biocide to control biological growth. At some point, the minerals in the water become concentrated beyond the effectiveness of the chemical additives, and they must be diluted by blowing down water from the bottom of the cooling tower basin and cleaner water to make up for the lost water volume. If managed well, this process provides a sound operating system; however, it requires a large amount of 
chemicals, makeup water, and personal attention. There are several alternative water treatment systems that employ a variety of technologies.

This document provides the results of a measurement and validation study for a chemical-free water treatment technology from Dynamic Water Technologies, LLC (DWT) and Universal Environmental Technologies (UET). The DWT-UET technology was deployed on a cooling tower in a large office building in Los Angeles, California. The baseline performance and DWTUET system performances were monitored during the 2018 cooling season.

This demonstration project had three primary objectives:

1. Verify water and energy reductions for the demonstration building

2. Verify operations and maintenance costs reductions and plant personnel acceptance

3. Provide decision-making information for building and energy managers to assess the technology applicability for other buildings. 


\section{Technology Description}

DWT partnered with UET to bring this chemical-free cooling tower water treatment system to the United States. The technology is designed to provide a high level of water treatment without the use of cooling tower chemicals. According to DWT, the system maintains a dynamic water equilibrium that manages scale, minimizes corrosion, and controls biological growth, which leads to reduced water discharge (blowdown) and overall water consumption, lower maintenance costs, and energy savings due to cleaner heat exchanger surfaces. The process removes scale from the water in a reactor instead of relying on blowdown to eliminate minerals.

The technology uses a carefully controlled electrolysis process to split water into $\mathrm{H}^{+}$and $\mathrm{OH}^{-}$ ions inside the reactor. The high concentration of $\mathrm{OH}^{-}$ions at the cathode lowers the $\mathrm{pH}$ and leads to a high concentration of $\mathrm{CO}_{3}{ }^{-2}$ (bicarbonate ions), which accelerates the precipitation of the hard minerals and silica inside the reactor instead of on tower surfaces and in the heat exchanger tubes. The system also maintains a dynamic equilibrium between the $\mathrm{pH}$ and alkalinity to minimize corrosion. Additionally, the system activates the chloride naturally present in the water, creating chlorine, which acts as a biocide. The result is a system that drastically increases the cycles of concentration and minimizes the blowdown, thereby saving water. The control of the scale results in cleaner heat transfer surfaces and reduced energy consumption. Cleaner water also creates a more reliable system that should also have longer overall equipment life.

The system is installed to treat a side stream taken from the condenser water line leaving the cooling tower and returned to the cooling tower basin after treatment. A schematic of a typical installation is shown in Figure 2. Maintenance consists of monthly system inspection, cleaning scale from the reactor cores quarterly, and replacing the titanium reactor anode every $2-5$ years.

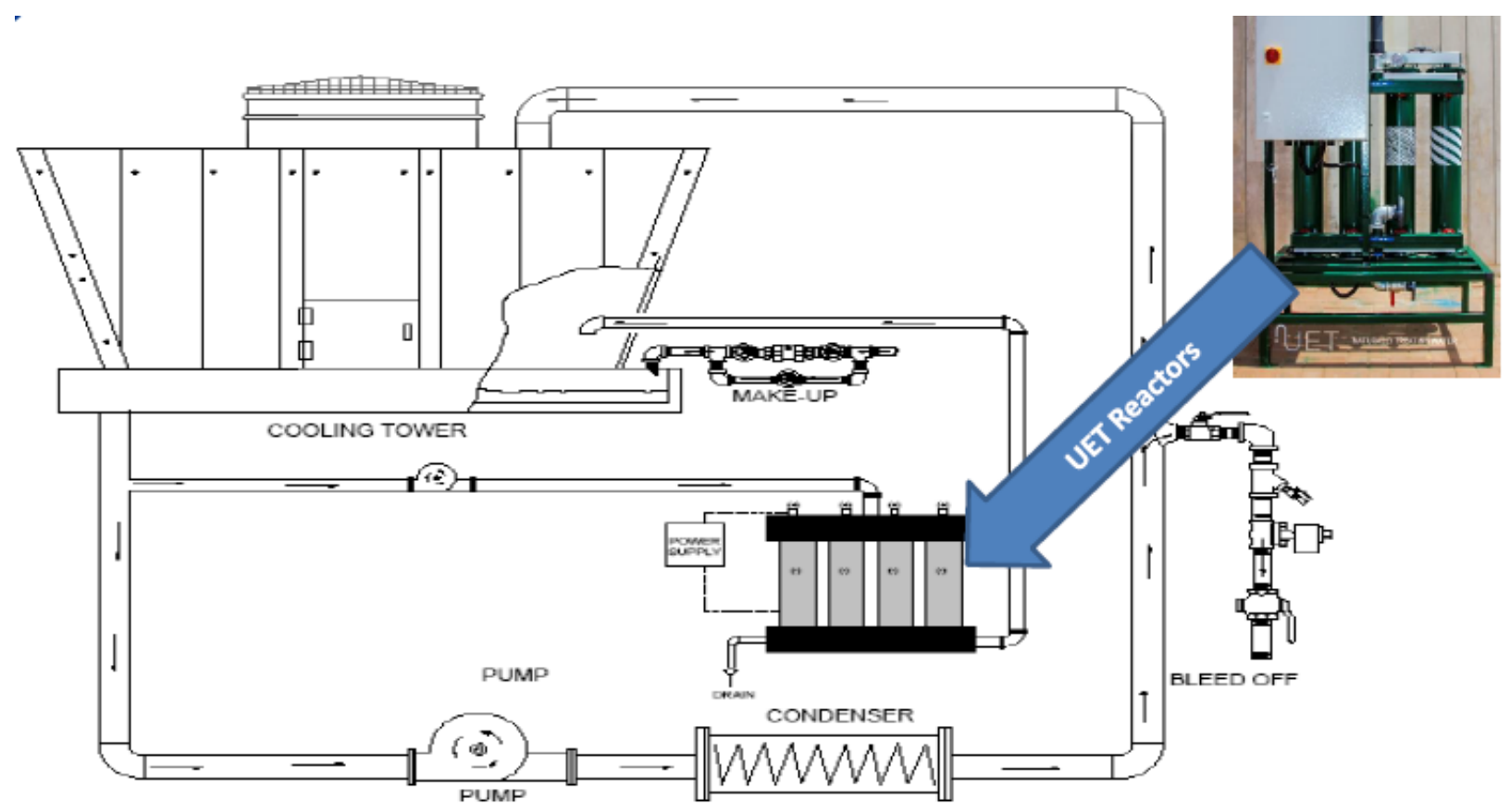

Figure 2. UET system schematic. Image courtesy of Dynamic Water Technologies 


\section{Evaluation Plan}

\subsection{Evaluation Design}

This technology validation study compared the operation of the chilled water system with and without the technology installed. The period without the technology installed is termed the baseline and is meant to represent as-is operation of the building systems.

Primary objectives of the study include assessing:

1. System water savings

2. System energy savings

3. Operations, maintenance, and chemical savings

4. Impact on corrosion, scaling, and biological contamination

5. Cost-effectiveness.

Building on these objectives, Table 1 shows the general performance objectives, performance metrics, and performance targets for this technology demonstration. Chiller plant energy savings is highly dependent on existing conditions and scale buildup in the system that would reduce heat transfer effectiveness. It is also difficult to determine chiller plant energy savings during a relatively short period in a dynamic system with multiple chillers, which is why the target for chiller energy savings is $0 \%$ to $5 \%$. 
Table 1. Quantitative Performance Metrics and Targets

\begin{tabular}{|l|l|l|}
\hline \multicolumn{1}{|c|}{$\begin{array}{c}\text { Technology } \\
\text { Performance } \\
\text { Objective }\end{array}$} & \multicolumn{1}{|c|}{ Performance Metric(s) } & \multicolumn{1}{c|}{ Preliminary Performance Target } \\
\hline Water savings & Makeup water flow rate & $>20 \%$ makeup water savings \\
\hline Sewer savings & Blowdown water flow rate & $>80 \%$ reduction in sewer discharges \\
\hline Energy savings & Chiller plant energy consumption & $0 \%-5 \%$ \\
\hline $\begin{array}{l}\text { Maintenance } \\
\text { savings }\end{array}$ & $\begin{array}{l}\text { Maintenance records for current cost } \\
\text { of chemicals and labor. Maintenance } \\
\text { records during demonstration period } \\
\text { and estimated future maintenance } \\
\text { for the DWT system. }\end{array}$ & $\begin{array}{l}100 \% \text { reduction in added chemicals and } \\
\text { decrease in maintenance costs including } \\
\text { eliminated costs for mechanical cleaning and } \\
\text { descaling is less than the annualized costs for } \\
\text { cleaning and maintaining the new system }\end{array}$ \\
\hline $\begin{array}{l}\text { Safety and handling } \\
\text { savings }\end{array}$ & $\begin{array}{l}\text { Insurance and cost for handling } \\
\text { chemicals and waste material }\end{array}$ & $\begin{array}{l}\text { Net decrease in cost for handling chemicals } \\
\text { and waste material }\end{array}$ \\
\hline Equipment life & Level of corrosion & $\begin{array}{l}\text { Decrease in corrosivity from visual inspections } \\
\text { and water chemistry: } 6-8 \text { on the RSI and } \\
<600 \text { mV ORP }\end{array}$ \\
\hline Water quality & Water quality monitoring & $\begin{array}{l}\text { Water quality meets site-specific standards } \\
\text { (attributes of interest may include conductivity, } \\
\text { pH, hardness, alkalinity, silica high range, } \\
\text { chloride anions, salt anions, sulfate anions, } \\
\text { phosphate, copper, iron, and biological } \\
\text { growth) }\end{array}$ \\
\hline Cost-effectiveness & Simple payback & $<4$ years payback \\
\hline
\end{tabular}

\subsection{Test Site}

\subsubsection{Building Description}

The demonstration was performed at the Los Angeles James K. Hahn City Hall East located at 200 N. Main St, Los Angeles, California, as shown in Figure 3. The facility is an 18-story office building with a floor area of approximately 530,000 $\mathrm{ft}^{2}$. The chilled water plant contains two 500-ton and two 800-ton chillers and provides chilled water to serve this facility and at times to an adjacent building. Three of the chillers are from York and one is from Carrier. There are four cooling towers on the roof, each with two fans and two basins. The cooling tower basins are connected through a common header.

The building automation system (BAS) is managed by Johnson Controls, Inc. They provided the performance data from the BAS on a weekly basis. 


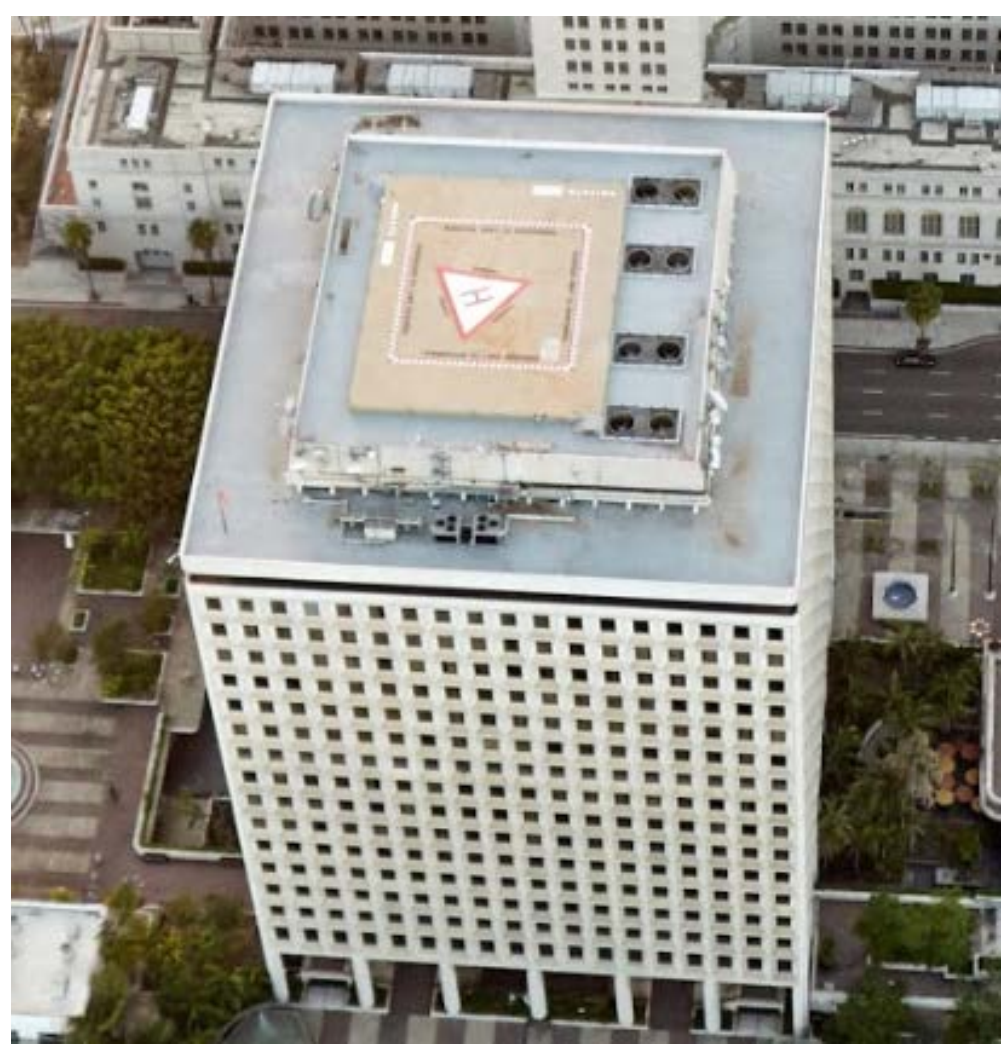

Figure 3. LA City Hall East with view of the cooling towers. Photo $\odot 2017$ Google, Map Data

The legacy water treatment system was a typical chemical-based approach maintained by a service contractor with weekly inspection, water chemistry checks, and dip tests taken to monitor biological growth. The primary chemicals used were phosphonate and nitrite with an automated chemical feed to control scale, corrosion, and biological growth, and additional chemicals were added as needed. The conductivity setting was adjusted to maintain the water chemistry in a safe range for scale and corrosion, usually between $2,400 \mu \mathrm{S} / \mathrm{cm}$ and 3,500 $\mu \mathrm{S} / \mathrm{cm}$. The blowdown valve was controlled to maintain the tower basin conductivity below the set point. The towers and chiller condensers were cleaned once per year.

For the baseline performance of this cooling plant, scale was controlled through maintaining chemistry balance, addition of scale inhibitors, and blowdown, which was controlled by the conductivity set point. The only removal mechanism of minerals causing scale was through blowdown of the concentrated minerals in the tower basin and dilution from the makeup water.

\subsubsection{Technology Installation}

The DWT-UET system consists of a reactor skid, small pump, small air compressor, and controller. This system draws water from the common condenser header and feeds the treated water to two of the cooling tower basins as shown for the UET-1 skid in Figure 4. An identical reactor skid is installed between cooling towers 3 and 4 . Figure 5 shows a picture of one of the installed reactor skids. Installation of the DWT-UET system is relatively easy but requires space for the space for the reactor skid, new piping to connect the system, $120 \mathrm{~V}$ power for the controller, $120 \mathrm{~V}$ or $220 \mathrm{~V}$ power for the circulation pump, and control wiring. 


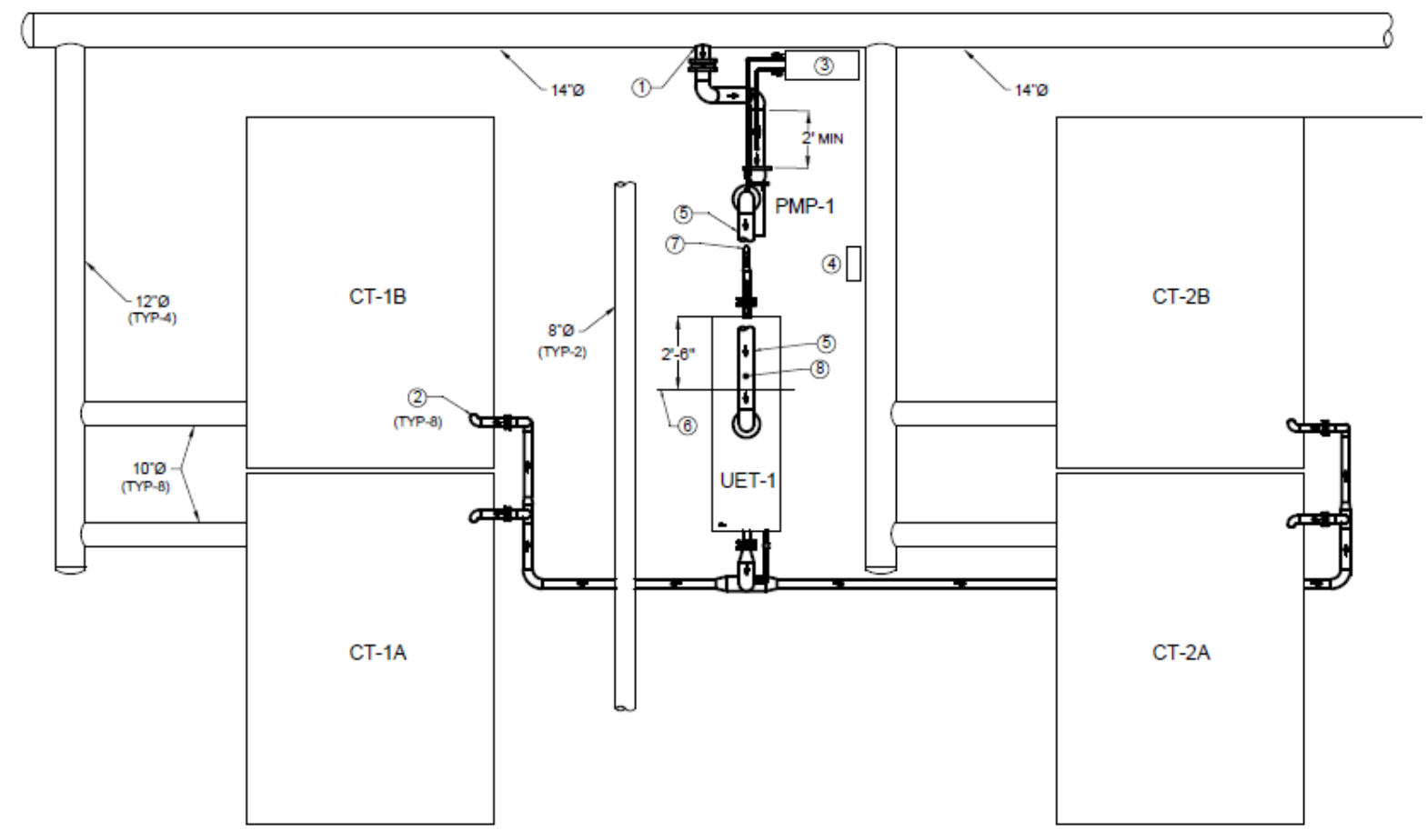

Figure 4. UET reactor installation for cooling towers 1 and 2. Image courtesy of Dynamic Water Technologies

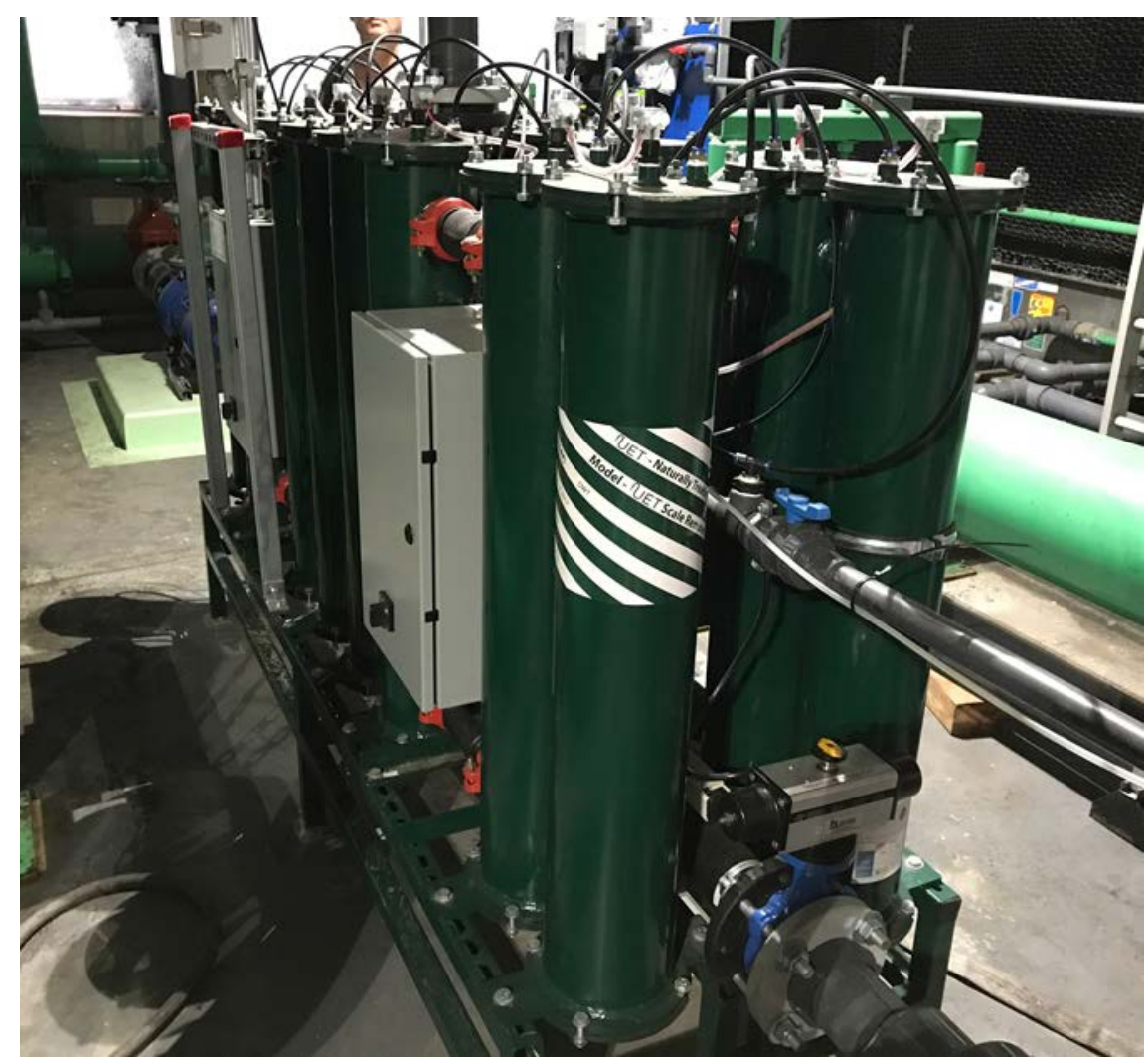

Figure 5. One of two UET reactor skid installations. Photo by Sammy Houssainy 


\subsection{Methodology}

\subsubsection{Quantitative Study Design}

Table 2 identifies the measurements used to determine the water and energy performance. Table 2 also describes the source of data, collection frequency, and the type of instrument used.

Table 2. Monitoring and Instrumentation

\begin{tabular}{|l|l|c|l|l|}
\hline \multicolumn{1}{|c|}{ Monitoring Point } & \multicolumn{1}{|c|}{ Sensor } & Units & Frequency & \multicolumn{1}{|c|}{ Notes } \\
\hline Blowdown flow rate & Existing site meter & $\begin{array}{c}\text { gpm, } \\
\text { total }\end{array}$ & $10 \mathrm{~min}$ & $\begin{array}{l}\text { Data trended through } \\
\text { BAS from Advantage } \\
\text { controller }\end{array}$ \\
\hline $\begin{array}{l}\text { Blowdown } \\
\text { conductivity }\end{array}$ & Existing site meter & avg & $5 \mathrm{~min}$ & $\begin{array}{l}\text { From Advantage } \\
\text { controller }\end{array}$ \\
\hline $\begin{array}{l}\text { Makeup water flow } \\
\text { rate }\end{array}$ & Existing site meter & $\begin{array}{l}\text { gpm, } \\
\text { total }\end{array}$ & $10 \mathrm{~min}$ & $\begin{array}{l}\text { Data trended through } \\
\text { BAS }\end{array}$ \\
\hline Chiller power & $\begin{array}{l}\text { Existing site meters } \\
\text { and new meter for } \\
\text { Carrier chiller }\end{array}$ & $\begin{array}{l}\mathrm{kWh}, \\
\text { total }\end{array}$ & $15 \mathrm{~min}$ & $\begin{array}{l}\text { Data trended through } \\
\text { BAS }\end{array}$ \\
\hline $\begin{array}{l}\text { Cooling tower fan } \\
\text { power }\end{array}$ & $\begin{array}{l}\text { Variable frequency } \\
\text { drive output }\end{array}$ & $\begin{array}{l}\mathrm{kWh}, \\
\text { total }\end{array}$ & $15 \mathrm{~min}$ & $\begin{array}{l}\text { Data trended through } \\
\text { BAS }\end{array}$ \\
\hline Chilled water pumps & $\begin{array}{l}\text { Variable frequency } \\
\text { drive output }\end{array}$ & $\begin{array}{l}\mathrm{kWh}, \\
\text { total }\end{array}$ & $15 \mathrm{~min}$ & $\begin{array}{l}\text { Data trended through } \\
\text { BAS }\end{array}$ \\
\hline $\begin{array}{l}\text { DWT-UET reactor } \\
\text { skid }\end{array}$ & $\begin{array}{l}\text { System runtime and } \\
\text { one-time power } \\
\text { measurement }\end{array}$ & $\begin{array}{l}\mathrm{kWh}, \\
\text { total }\end{array}$ & once & $\begin{array}{l}\text { Estimate from one-time } \\
\text { power measurement } \\
\text { from DWT }\end{array}$ \\
\hline Slip-stream pump & $\begin{array}{l}\text { System runtime and } \\
\text { one-time power } \\
\text { measurement }\end{array}$ & $\begin{array}{l}\mathrm{kWh} \\
\text { total }\end{array}$ & once & $\begin{array}{l}\text { Estimate from one-time } \\
\text { power measurement } \\
\text { from DWT }\end{array}$ \\
\hline
\end{tabular}

\subsubsection{Qualitative Study Design}

Although qualitative objectives were not included in the study design, a qualitative assessment of the DWT-UET system was conducted based on review of system maintenance reports, review of water quality data, and communications with the facilities staff and the vendor.

\subsubsection{Data Analysis}

A prevalidation phase performance was established with weekly water chemistry reporting and monthly utility data from November 2017 through May 2018. The detailed energy and water data from Table 2 were available starting March 29, 2018, through July 8, 2018. The DWT system was started on July 9, 2018 and the technology validation data were available through December 31, 2018. The data collection periods of testing are summarized in Table 3. 
Table 3. Description of Test Periods

\begin{tabular}{|l|l|l|}
\hline \multicolumn{1}{|c|}{ Test Period } & \multicolumn{1}{|c|}{ Dates } & \multicolumn{1}{c|}{ Notes } \\
\hline Prevalidation & $\begin{array}{l}11 / 2017 \text { to } \\
4 / 2018\end{array}$ & Period of weekly water chemistry test data reporting \\
\hline Baseline & $\begin{array}{l}4 / 23 / 2018 \text { to } \\
7 / 5 / 2018\end{array}$ & $\begin{array}{l}\text { 10 days were removed because of missing or faulty } \\
\text { data or unknown system operation, 64 days used }\end{array}$ \\
\hline $\begin{array}{l}\text { DWT-UET } \\
\text { Acclimation }\end{array}$ & $\begin{array}{l}7 / 8 / 2018 \text { to } \\
7 / 26 / 2018\end{array}$ & Not used for performance determination \\
\hline $\begin{array}{l}\text { DWT-UET } \\
\text { Validation }\end{array}$ & $\begin{array}{l}7 / 27 / 2018 \text { to } \\
11 / 30 / 2018\end{array}$ & 127 days used and no days removed \\
\hline $\begin{array}{l}\text { Total building } \\
\text { system data } \\
\text { collection }\end{array}$ & $\begin{array}{l}3 / 29 / 2018 \text { to } \\
12 / 31 / 2018\end{array}$ & $\begin{array}{l}\text { Full period of data collection period from the building } \\
\text { systems. Blowdown water data was not collected } \\
\text { from 3/29 to 4/23. }\end{array}$ \\
\hline
\end{tabular}

The water consumption in the cooling towers is a function of several variables and linear multivariable regression models were developed using the $\mathrm{R}$ programming language with RStudio (RStudio 2019). These models were then used to estimate annual water consumption and savings.

\subsubsection{Baseline Model Development}

The baseline model was created in R using daily average and daily total values for 64 days of measured data. Ten days of data were removed because of measurement failures or known maintenance issues that caused the system to produce extrema that were unrepresentative of typical operating conditions of the system. These days are May 1-3, May 7, May 10-11, May 17-18, and June 28-29. In addition, there were occasional periods with 1 to 2 time steps of missing or faulty data that were filled in by averaging adjacent data. The data are presented in Appendix A.

The baseline linear regression model with the best fit to the measured data uses workday (binary operator; $0=$ =eekend, $1=$ =weekday), daily average ambient dry-bulb and wet-bulb temperatures $\left({ }^{\circ} \mathrm{F}\right)$, daily total cooling load (ton-hr, refrigeration), and the daily cooling tower conductivity setpoint $(\mu \mathrm{S} / \mathrm{cm})$ to estimate the daily makeup water. The resulting baseline model equation is:

$$
y=c 1 * x 1+c 2 * x 2+c 3 * x 3+c 4 * x 4+c 5 * x 5+\text { intercept }
$$

Where:

- $\mathrm{y}=$ daily makeup water (gal)

- $\mathrm{x} 1=$ workday (binary operator; $0=$ weekend, $1=$ =weekday)

- $\mathrm{x} 2=$ daily average ambient dry-bulb temperature $\left({ }^{\circ} \mathrm{F}\right)$

- $\mathrm{x} 3=$ daily average ambient wet-bulb temperature $\left({ }^{\circ} \mathrm{F}\right)$

- $\mathrm{x} 4=$ daily total cooling load (ton-hr, refrigeration)

- $\mathrm{x} 5=$ daily cooling tower conductivity setpoint $(\mu \mathrm{S} / \mathrm{cm})$

For each coefficient (c1-c5) in Eq. (1), R calculates the standard error, the t-value (the t-test associated with testing the significance of the parameter [coefficient divided by the standard 
error]), and the $\mathrm{p}$-value or probability value for that $\mathrm{t}$-test (the proportion of the $\mathrm{t}$ distribution at that degree of freedom, which is greater than the absolute value of the t statistic). These values are in Table 4. The larger the absolute t-value and the smaller the p-value, the more significant the variable is to the correlation. The daily cooling load and dry-bulb temperature are the most significant variables and the conductivity and workday are the least significant variables.

Table 4. Baseline Linear Model Coefficients and Associated Statistics

\begin{tabular}{|l|r|r|r|r|}
\hline Coefficient & Value & $\begin{array}{c}\text { Standard } \\
\text { Error }\end{array}$ & t-value & p-value \\
\hline intercept & $-1.493 \mathrm{E}+04$ & $9.16 \mathrm{E}+03$ & -1.631 & 0.10826 \\
\hline c1 & $5.752 \mathrm{E}+01$ & $8.26 \mathrm{E}+02$ & 0.07 & 0.94469 \\
\hline c2 & $3.956 \mathrm{E}+02$ & $1.17 \mathrm{E}+02$ & 3.368 & 0.00135 \\
\hline c3 & $-1.589 \mathrm{E}+02$ & $1.77 \mathrm{E}+02$ & -0.897 & 0.37332 \\
\hline c4 & $1.497 \mathrm{E}+00$ & $2.37 \mathrm{E}-01$ & 6.313 & $4.12 \mathrm{E}-08$ \\
\hline c5 & $-1.649 \mathrm{E}-01$ & $5.07 \mathrm{E}-01$ & -0.326 & 0.74591 \\
\hline
\end{tabular}

Table 5 shows the statistical significance of the baseline model compared to the measured data. The coefficient of determination $\left(\mathrm{R}^{2}\right)$ values and model statistical values are within the American Society of Heating, Refrigerating and Air-Conditioning Engineers (ASHRAE) Guideline 142014 requirements for field measurements and a linear regression model (ASHRAE 2014). Overall, the model slightly underestimates the actual water consumption.

Table 5. Statistical Values of Baseline Model

\begin{tabular}{|l|l|l|c|}
\hline \multicolumn{1}{|c|}{ Parameter } & Acronym & \multicolumn{1}{c|}{ Value } & $\begin{array}{c}\text { Guideline 14 } \\
\text { Requirements }\end{array}$ \\
\hline Coefficient of multiple determination & Multiple $\mathrm{R}^{2}$ & 0.921 & $>0.75$ \\
\hline Adjusted coefficient of determination & Adjusted $\mathrm{R}^{2}$ & 0.914 & $>0.75$ \\
\hline Root-mean-square error & RMSE & 1,365 & \\
\hline Coefficient of variation of the root-mean-square error & CV(RMSE) & $9.35 \%$ & \\
\hline Normalized mean bias error & NMBE & $0.00391 \%$ & $<0.5 \%$ \\
\hline
\end{tabular}

\subsubsection{DWT-UET Model Development}

The DWT-UET validation period represents measurements taken after the DWT-UET water treatment system was activated and operation stabilized. The DWT-UET validation period ran from July 27, 2018, to November 30, 2018 (127 days). Similar to the baseline model, a DWTUET linear regression model to estimate makeup water was developed using the data gathered during this time period. No days of data were removed. The data are presented in Appendix C.

The DWT-UET linear regression model developed uses workday (binary operator; $0=$ weekend, $1=$ weekday), daily average ambient dry- and wet-bulb temperatures $\left({ }^{\circ} \mathrm{F}\right)$, and the daily total 
cooling load (ton-hr, refrigeration) to estimate the daily makeup water. With the DWT-UET system installed and operating, the daily cooling tower conductivity setpoint was fixed at 5,500 $\mu \mathrm{S} / \mathrm{cm}$ and remained unchanged throughout the monitoring period. Therefore, it is not included on the DWT-UET linear regression model. The resulting DWT-UET model equation is:

$$
y=c 1 * x 1+c 2 * x 2+c 3 * x 3+c 4 * x 4+\text { intercept }
$$

Where:

- $\quad \mathrm{y}=$ daily makeup water (gal)

- $\quad \mathrm{x} 1=$ workday (binary operator; $0=$ weekend, $1=$ weekday)

- $\quad \mathrm{x} 2=$ daily average ambient dry-bulb temperature $\left({ }^{\circ} \mathrm{F}\right)$

- $\quad \mathrm{x} 3$ = daily total cooling load (ton-hr, refrigeration)

- $\mathrm{x} 4=$ daily average ambient wet-bulb temperature $\left({ }^{\circ} \mathrm{F}\right)$

The value for each coefficient in Eq. (2) and the statistical values are shown in Table 6. The drybulb temperature and cooling load are the most significant variables, but the workday and wetbulb temperature are also significant.

Table 6. DWT-UET Linear Model Coefficients and Associated Statistics

\begin{tabular}{|l|r|r|r|r|}
\hline Coefficient & \multicolumn{1}{|c|}{ Value } & \multicolumn{1}{c|}{$\begin{array}{c}\text { Standard } \\
\text { Error }\end{array}$} & t-value & \multicolumn{1}{c|}{ p-value } \\
\hline intercept & $-4.15 \mathrm{E}+04$ & $3.50 \mathrm{E}+03$ & -11.856 & $<2 \mathrm{E}-16$ \\
\hline c1 & $1.63 \mathrm{E}+03$ & $4.04 \mathrm{E}+02$ & 4.037 & $9.53 \mathrm{E}-05$ \\
\hline c2 & $6.98 \mathrm{E}+02$ & $5.91 \mathrm{E}+01$ & 11.818 & $<2 \mathrm{E}-16$ \\
\hline c3 & $7.40 \mathrm{E}-01$ & $8.65 \mathrm{E}-02$ & 8.554 & $4.36 \mathrm{E}-14$ \\
\hline c4 & $1.04 \mathrm{E}-01$ & $2.94 \mathrm{E}-02$ & 3.534 & 0.000581 \\
\hline
\end{tabular}

Table 7 shows the statistical significance of the DWT-UET model compared to the measured data. The coefficient of determination $\left(\mathrm{R}^{2}\right)$ values and model statistical values are within the ASHRAE Guideline 14-2014 requirements for field measurements and a linear regression model (ASHRAE 2014). Overall, the model slightly underestimates the actual water consumption.

Table 7. Statistical Values of DWT-UET Model

\begin{tabular}{|l|l|l|c|}
\hline \multicolumn{1}{|c|}{ Parameter } & \multicolumn{1}{|c|}{ Acronym } & Value & $\begin{array}{c}\text { Guideline 14 } \\
\text { Requirements }\end{array}$ \\
\hline Coefficient of multiple determination & Multiple $\mathrm{R}^{2}$ & 0.924 & $>0.75$ \\
\hline Adjusted coefficient of determination & Adjusted $\mathrm{R}^{2}$ & 0.922 & $>0.75$ \\
\hline Root-mean-square error & RMSE & 1,638 & \\
\hline Coefficient of variation of the root-mean-square error & CV(RMSE) & $9.11 \%$ & \\
\hline Normalized mean bias error & NMBE & $0.0343 \%$ & $<0.5 \%$ \\
\hline
\end{tabular}




\subsubsection{Cooling Load Model Development}

To estimate annual performance, a linear regression model of the building cooling load was developed to estimate the cooling load for periods not directly measured in this study. The building cooling load is primarily a function of the ambient dry-bulb temperature and the workday/weekend, and to a lesser degree, a function of ambient wet-bulb temperature. The model was developed using measured data for these parameters from April 23 to November 30, 2018.

The cooling load linear regression model uses workday (binary operator; $0=$ weekend, $1=$ weekday), daily average ambient dry- and wet-bulb temperatures $\left({ }^{\circ} \mathrm{F}\right)$ to estimate the daily total cooling load (ton-hr, refrigeration). The resulting model equation is:

$$
y=c 1 * x 1+c 2 * x 2+c 3 * x 3+\text { intercept }
$$

Where:

- $\quad \mathrm{y}=$ daily cooling load (ton-hr)

- $\quad \mathrm{x} 1=$ workday (binary operator; $0=$ weekend, $1=$ weekday)

- $\quad \mathrm{x} 2$ = daily average ambient dry-bulb temperature $\left({ }^{\circ} \mathrm{F}\right)$

- $\mathrm{x} 3=$ daily average ambient wet-bulb temperature $\left({ }^{\circ} \mathrm{F}\right)$

The values for each coefficient in Eq. $(y=c 1 * x 1+c 2 * x 2+c 3 * x 3+$ intercept (3) and the statistical values are shown in Table 8 . The dry-bulb temperature and the workday are the most significant variables.

Table 8. Cooling Load Linear Model Coefficients and Associated Statistics

\begin{tabular}{|l|c|c|r|r|}
\hline Coefficient & Value & $\begin{array}{c}\text { Standard } \\
\text { Error }\end{array}$ & t-value & p-value \\
\hline intercept & $-3.035 \mathrm{E}+04$ & $1.620 \mathrm{E}+03$ & -18.731 & $<2 \mathrm{E}-16$ \\
\hline c1 & $2.912 \mathrm{E}+03$ & $2.497 \mathrm{E}+02$ & 11.664 & $<2 \mathrm{E}-16$ \\
\hline c2 & $5.744 \mathrm{E}+02$ & $2.324 \mathrm{E}+01$ & 24.715 & $<2 \mathrm{E}-16$ \\
\hline c3 & $-4.24 \mathrm{E}-02$ & $2.405 \mathrm{E}-02$ & -1.763 & 0.0796 \\
\hline
\end{tabular}

Table 9 shows the statistical significance of the cooling load model compared to the measured data. This model is not as good of a fit as the water models, but it meets the Guideline 14 requirements and is considered good enough to estimate the building cooling load as an input to the cooling tower makeup water models. 
Table 9. Statistical Values of Cooling Load Model

\begin{tabular}{|l|l|l|c|}
\hline \multicolumn{1}{|c|}{ Parameter } & \multicolumn{1}{|c|}{ Acronym } & \multicolumn{1}{c|}{ Value } & \multicolumn{1}{c|}{$\begin{array}{c}\text { Guideline 14 } \\
\text { Requirements }\end{array}$} \\
\hline Coefficient of multiple determination & Multiple $\mathrm{R}^{2}$ & 0.8191 & $>0.75$ \\
\hline Adjusted coefficient of determination & Adjusted $\mathrm{R}^{2}$ & 0.8162 & $>0.75$ \\
\hline Root-mean-square error & RMSE & 1548 & \\
\hline Coefficient of variation of the root-mean-square error & CV(RMSE) & $13.9 \%$ & \\
\hline Normalized mean bias error & NMBE & $0.042 \%$ & $<0.5 \%$ \\
\hline
\end{tabular}




\section{Results}

\subsection{System Operation}

The legacy water treatment system followed a typical chemical-based approach with weekly water testing and adjustments of chemical injections and basin conductivity set points to maintain water quality within specifications. During the baseline period, the conductivity set point started at 3,400 $\mu \mathrm{S} / \mathrm{cm}$ and was changed to $2,400 \mu \mathrm{S} / \mathrm{cm}$ on May 18 because the conductivity cycles were high out of range. The DWT-UET system was turned on July 9, 2018, and the conductivity set point was changed to $5,400 \mu \mathrm{S} / \mathrm{cm}$. An unexpected source of bleed water occurred during the setup and commissioning, which led to excessive makeup water to the basin (and subsequent basin overflow). The fault was noted by the steep drop in conductivity and was stopped on July 16. After this fault was corrected, the conductivity increased steadily to the new set point on August 5. The tower basin conductivity as recorded by the advantage controller over the baseline and validation periods is shown in Figure 6 . The conductivity values recorded by the advantage controller during the baseline period (prior to July 9), were approximately $600 \mu \mathrm{S} / \mathrm{cm}$ higher than the set point. The conductivity readings taken during the weekly maintenance checks were in line with these set points throughout the testing, which indicates that the advantage controller conductivity meter may have been out of calibration or fouled during the baseline period. These readings were not used in the analysis and do not affect the results.

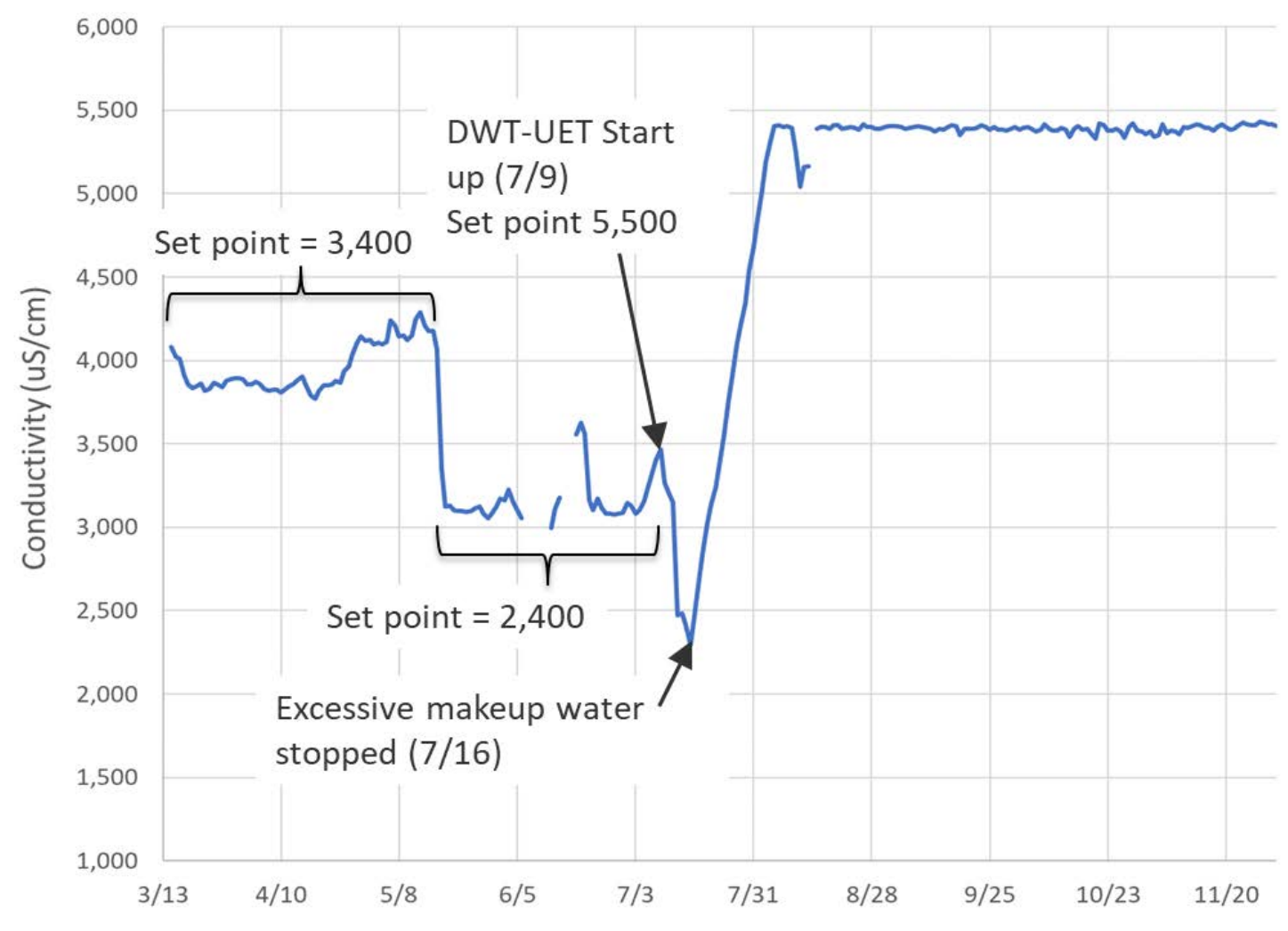

Figure 6. Cooling tower basin water conductivity 


\subsection{Quantitative Results}

\subsubsection{Water Performance}

Comparison of water consumption between the baseline and DWT-UET system cannot be accomplished with a direct comparison of measured data because the systems operated at different times with different conditions. The linear regression models for baseline and DWTUET operation from Sections 3.3.3.1 and 3.3.3.2 were used to estimate the water consumption with measured weather and building cooling load data. Figure 7 shows the estimated daily water consumption from the two models over the full period of data collection from March 29 to December 31,2018 . The gaps in the graphs are days with missing or faulty cooling load data.



Figure 7. Modeled daily water consumption from March 29 to December 31, 2018

To determine annual water savings, a complete weather and cooling load data file for 2018 was created from the on-site measured data combined with weather data taken from a nearby station and building cooling load data estimated from the linear regression model developed in Section 3.3.3.3 for periods with faulty or no data collection. The cooling load linear regression model represented by Eq. ( $\mathrm{y}=\mathrm{c} 1^{*} \mathrm{x} 1+\mathrm{c} 2^{*} \mathrm{x} 2+\mathrm{c} 3^{*} \mathrm{x} 3+$ intercept (3) was used to estimate the cooling load for January 1 to March 28 and a few days of missing or faulty data throughout the rest of the year. Daily average dry-bulb and wet-bulb temperatures for these periods were taken from a nearby Weather Underground station KQCT (WU 2019). Then, the baseline and DWTUET water-use models were run with this annual data file to estimate 2018 water savings for this building. The baseline regression model was run with two values for the conductivity set point to represent the two operating conditions during the baseline monitoring period with the results shown in Table 10 . The annual water savings are $20 \%$ with the baseline conductivity set point at $2,400 \mu \mathrm{S} / \mathrm{cm}$ and $19 \%$ with a conductivity set point of $3,400 \mu \mathrm{S} / \mathrm{cm}$. The uncertainty was determined according to ASHRAE Guideline 14 and the calculations are shown in Appendix D. 
Table 10. Estimated Annual Water Consumption and Savings for 2018

\begin{tabular}{|c|c|c|}
\hline Model & $\begin{array}{c}\text { Value } \\
\text { (Baseline Cond. 2,400) }\end{array}$ & $\begin{array}{c}\text { Value } \\
\text { (Baseline Cond. 3,400) }\end{array}$ \\
\hline Baseline Performance (gal) & $5,941,549$ & $5,882,350$ \\
\hline DWT-UET Performance (gal) & $4,779,942$ & $4,779,942$ \\
\hline Savings (gal) & $1,161,607$ & $1,102,408$ \\
\hline Savings $\%$ & $20 \%$ & $19 \%$ \\
\hline Uncertainty & $+/-1.6 \%$ at $90 \%$ confidence & $+/-1.6 \%$ at $90 \%$ confidence \\
\hline
\end{tabular}

The water savings with the DWT-UET system comes from the reduced need for blowdown; the evaporated water consumption is similar for both systems because this is related to the heat rejection from the chillers which is similar for both systems. The blowdown water (i.e., waste or sewer water) reduction is approximately equal to the water consumption savings, over 1 million gallons per year.

\subsubsection{Energy Performance}

The presence of scale on heat transfer surfaces such as condenser tubes increases the thermal resistance and decreases the heat transfer rate. The reduction in heat transfer reduces the effectiveness of the condenser to reject heat and overall chiller plant efficiency. The DWT-UET system claims to remove existing scale and improve the overall energy performance. This change in scale in the condenser tubes is potentially significant to energy performance but is a relatively small physical change and takes place over several months, making it difficult to measure changes in the energy performance. In addition, sequencing of the four chillers of different sizes and efficiencies and the operation of the cooling tower fans were not consistent during the validation period, making it challenging to determine small changes in energy performance. Two approaches to evaluating the energy performance were undertaken. First, linear regression models were developed for the energy consumption of the chillers for the baseline and DWT-UET operations. The models produced very similar results and no change in energy performance was observed.

The second approach was to compare the chiller plant efficiency (kW/ton) from periods with similar conditions and chiller run hours. The periods of May 31 to July 2 and September 29 to November 26 had similar weather conditions with the average temperature of $67.9^{\circ} \mathrm{F}$ and $68.7^{\circ} \mathrm{F}$. The hourly chiller plant load for weekdays and weekends is shown in Figure 8, and the chiller plant efficiencies are shown in Figure 9. The ambient temperature during the DWT test period was slightly warmer, and the chiller plant load was slightly higher than the baseline period. The weekday efficiencies are nearly identical, and the weekend efficiencies are very similar. Given the uncertainty in the chiller plant operation and measurements, we conclude that there is no measurable change in the energy performance during this period. Longer-term and more accurate measurements may reveal a change in the energy performance.

The energy consumption of the DWT-UET reactor skid, circulation pump, and air compressor is approximately $1 \%$ to $2 \%$ of the total cooling plant energy consumption based on measurements from another measurement and validation project of this technology (Tomberlin, Dean, and Deru 2018). This energy consumption is within the measurement uncertainty and was not noticeable in the results of this project. 


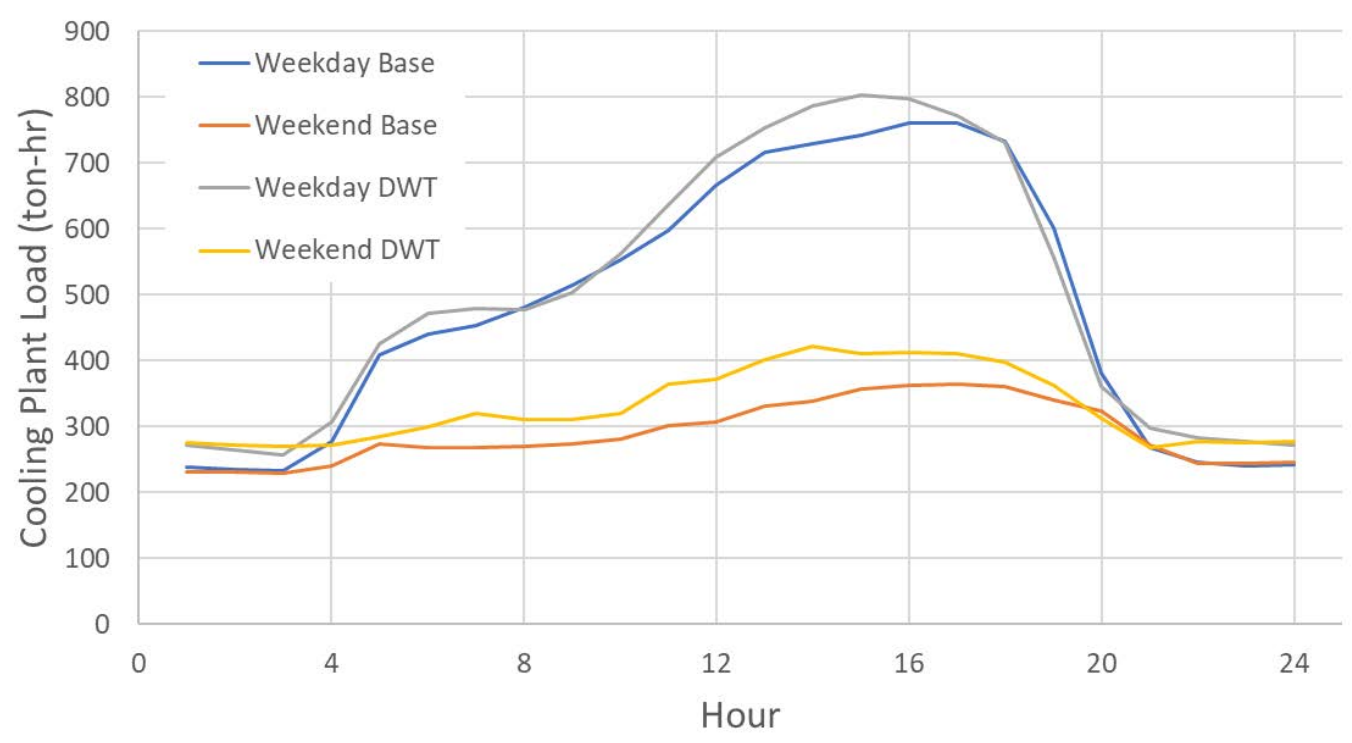

Figure 8. Chiller plant load during similar baseline and DWT test periods

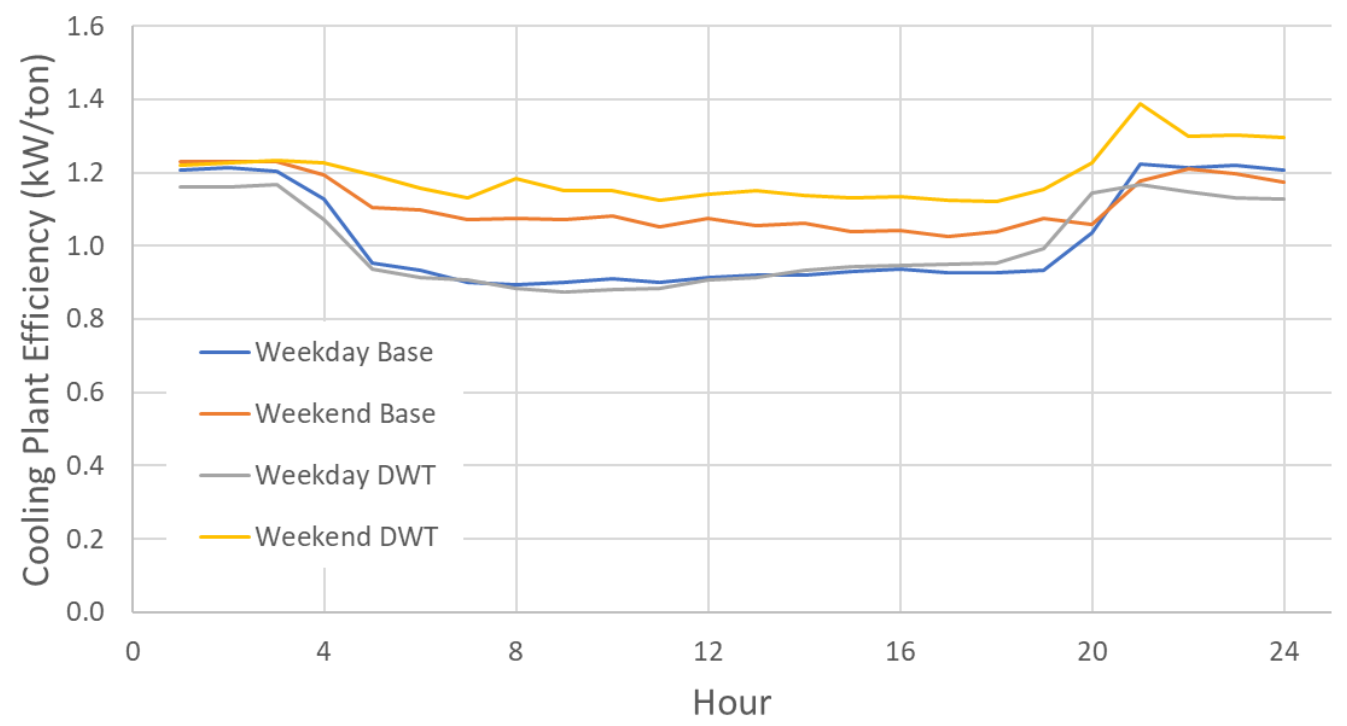

Figure 9. Chiller plant efficiency during similar baseline and DWT test periods

\subsubsection{Water Quality}

The purpose of water treatment systems is to establish conditions that maintain a balance between scale, corrosion, fouling, and biological growth, while minimizing water consumption and total costs. One way that the DWT-UET system reduces the potential for corrosion is by maintaining a higher $\mathrm{Ca}^{+2}$ ion concentration and slightly higher $\mathrm{pH}$ than chemical-based treatment systems. Chemical-based treatment systems may add sulfuric acid to reduce calcium carbonate scale. The DWT-UET system controls scale deposition by providing conditions in the 
reactors that are favorable to scale deposition, thus removing the minerals from the cooling water and avoiding scale in other parts of the cooling system.

The balance between calcium carbonate scaling and corrosive tendencies of water can be estimated with the Langelier Saturation Index (LSI) and the Ryznar Stability Index (RSI). LSI values below zero indicate a corrosive tendency for mild steel, and LSI values greater than zero indicate conditions favorable to calcium carbonate scaling. RSI values less than 6 indicate conditions favorable to calcium carbonate scaling, and RSI values greater than 7 indicate a higher tendency for mild steel corrosion. Cooling tower water systems are typically maintained with a slight scaling tendency to avoid corrosion problems. The LSI, RSI, and $\mathrm{pH}$ from June 2017 through January 2019 are shown in Figure 10. The DWT-UET system maintains a higher $\mathrm{pH}$, higher LSI, and lower RSI, showing a tendency for lower corrosion and higher calcium carbonate scale than the baseline treatment system. However, calcium carbonate preferentially precipitates in the reactors in the DWT-UET system, avoiding scale problems in the rest of the cooling system.

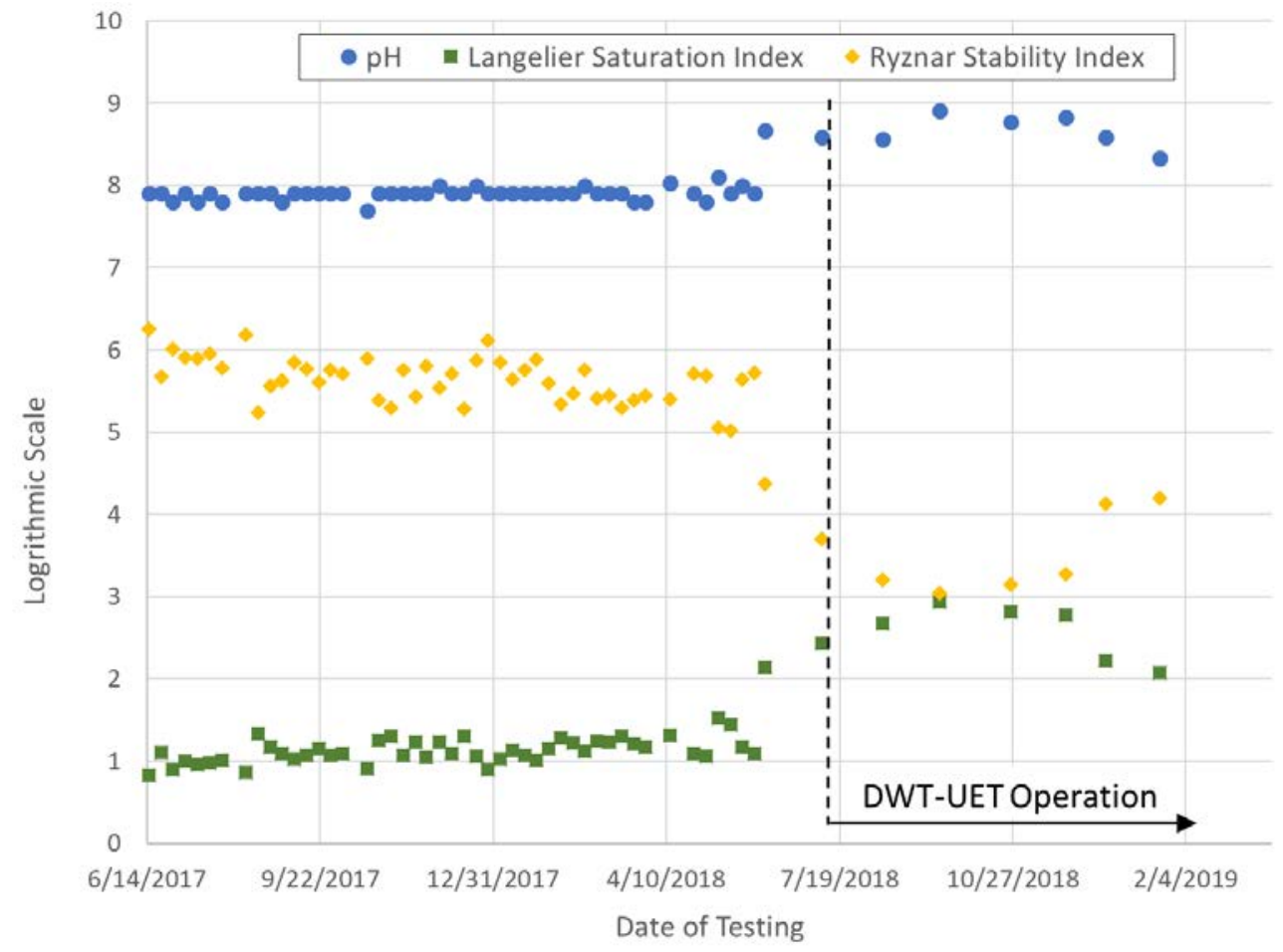

Figure 10. Corrosion and scaling indicators

\subsection{Cost-Effectiveness}

The cost-effectiveness is evaluated based a comparison of the water and sewer costs and maintenance and chemical costs for the two systems on an annual basis. The baseline cooling tower service contract and chemical costs are \$26,339 and the annual DWT-UET system service contract cost is $\$ 8,000$. The annual water and sewer costs for both systems and the savings are shown in Table 11, assuming sewer charges are based on $93 \%$ of the water usage. This analysis results in a total water and maintenance savings in the first year of $\$ 34,105$. An economic analysis of the DWT-UET technology for this installation is presented in Table 12. Two rebates 
were available for this installation of $\$ 6$ and $\$ 3.75$ per 1,000 gallons of water saved annually. With this rebate, the installed cost of the DWT-UET system is $\$ 188,674$ with a simple payback of 5.5 years. The 15 -year net present value is $\$ 160,700$, assuming a $2 \%$ inflation for water and maintenance costs and a 7\% discount rate. Additional savings from reduced annual maintenance cleaning requirements and increased equipment life are unknown but could be substantial and improve the economic value of this technology.

Table 11. Estimated Annual Cost Analysis

\begin{tabular}{|l|r|r|r|}
\hline \multicolumn{1}{|c|}{ Description } & \multicolumn{1}{c|}{ Baseline } & \multicolumn{1}{c|}{ DWT-UET } & \multicolumn{1}{c|}{ Savings } \\
\hline Water consumption (gal) & $5,941,549$ & $4,779,942$ & $\mathbf{1 , 1 6 1 , 6 0 7}$ \\
\hline Wastewater (gal) & $1,370,338$ & 208,731 & $\mathbf{1 , 1 6 1 , 6 0 7}$ \\
\hline Water costs $(\$ 5.40 /$ ccf) & $\$ 42,894$ & $\$ 34,508$ & $\$ \mathbf{8 , 3 8 6}$ \\
\hline $\begin{array}{l}\text { Sewer costs }(\$ 5.11 / \text { ccf, billed at } \\
93 \% \text { of water consumption) }\end{array}$ & $\$ 37,749$ & $\$ 30,369$ & $\mathbf{\$ 7 , 3 8 0}$ \\
\hline Annual service contract costs & $\$ 26,339$ & $\$ 8,000$ & $\mathbf{\$ 1 8 , 3 3 9}$ \\
\hline Total costs & $\$ 106,981$ & $\$ 72,876$ & $\mathbf{\$ 3 4 , 1 0 5}$ \\
\hline
\end{tabular}

Table 12. Technology Economic Analysis

\begin{tabular}{|l|r|}
\hline \multicolumn{1}{|c|}{ Parameter } & \multicolumn{1}{c|}{ Value } \\
\hline Technology cost & $\$ 175,000$ \\
\hline Installation cost & $\$ 25,000$ \\
\hline Rebates $(\$ 9.75 / 1,000$ gal saved) & $\$ 11,326$ \\
\hline Total cost & $\$ 188,674$ \\
\hline Annual water and maintenance savings & $\$ 34,105$ \\
\hline Simple payback & $\mathbf{5 . 5}$ years \\
\hline $\begin{array}{l}\text { Net present value } \\
\text { (15 years, 2\% inflation, } 7 \% \text { discount rate) }\end{array}$ & $\mathbf{\$ 1 6 0 , 7 0 0}$ \\
\hline
\end{tabular}

\subsection{Qualitative Results}

\subsubsection{System Maintenance}

The legacy cooling tower water treatment system was maintained under a service contract with weekly preventative maintenance that included water chemistry testing, system checks, sensor cleaning, and chemical treatments to maintain proper water quality. The legacy system used phosphonate- and nitrite-based chemical additives with an automated feed system. These systems were checked and filled on a weekly basis. Approximately 1,000 gallons of the phosphonate solution and 250 gallons of the nitrite solution were added during the service calls in 2017 . In addition, a liquid chloride solution was added occasionally to control biological growth. Nineteen gallons of the chloride solution were added in 2017. 
The DWT-UET system maintenance includes continuous monitoring through the Advantage controller, weekly water quality tests, monthly reactor checking, and quarterly reactor cleaning or as needed. The DWT-UET system eliminated the need for the phosphonate and nitrite solutions. Under most conditions, the DWT-UET system uses the existing chlorides in the municipal water systems to create biocides. Additional chlorine was added as a precaution during the first few months of operation for this installation and was phased out toward the end of 2018.

The legacy annual maintenance included cleaning of the cooling towers and chillers to clean the basins of mud and debris, pressure wash the cooling tower media, and conduct eddy current tests on the chiller tubes. The chiller barrels had not been cleaned for approximately three years prior to the DWT-UET system installation. A borescope of the condenser tubes on July 18 revealed substantial scale buildup with several areas with no rifling visible in the tube.

Under the DWT-UET system, the first reactor cleaning was on September 10 after 2 months of operation and $507 \mathrm{lb}$ of scale were removed from the reactors. The scale in this first cleaning included scale removal from the makeup water and from system descaling. Images of the scale in the reactor cores from October 26, 2018, and November 27, 2018, are shown in Figure 11. A borescope of the condenser tubes was conducted on October 30, 2018, and a noticeable amount of scale had been removed, revealing more of the rifling, as shown in Figure 12. It is expected that the reduction in scale buildup will allow for a faster and less aggressive annual chiller maintenance by not having to use the aggressive brushes to remove scale while cleaning the tubes. There was also a noticeable reduction of scale on the cooling tower media, which should help extend the life of the media due to the reduction in time of the pressure washing of the cooling tower media.
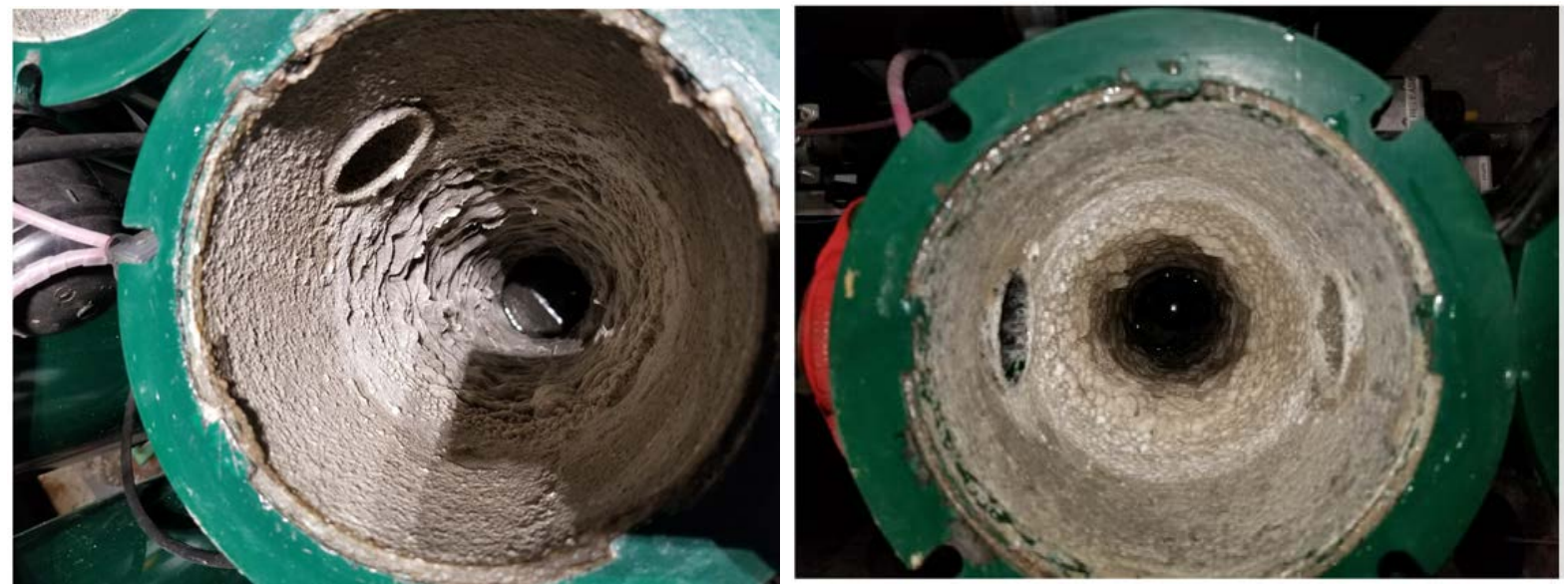

Figure 11. Reactor cores on October 26, 2018, and November 27, 2018. Photos by Dynamic Water Technologies 

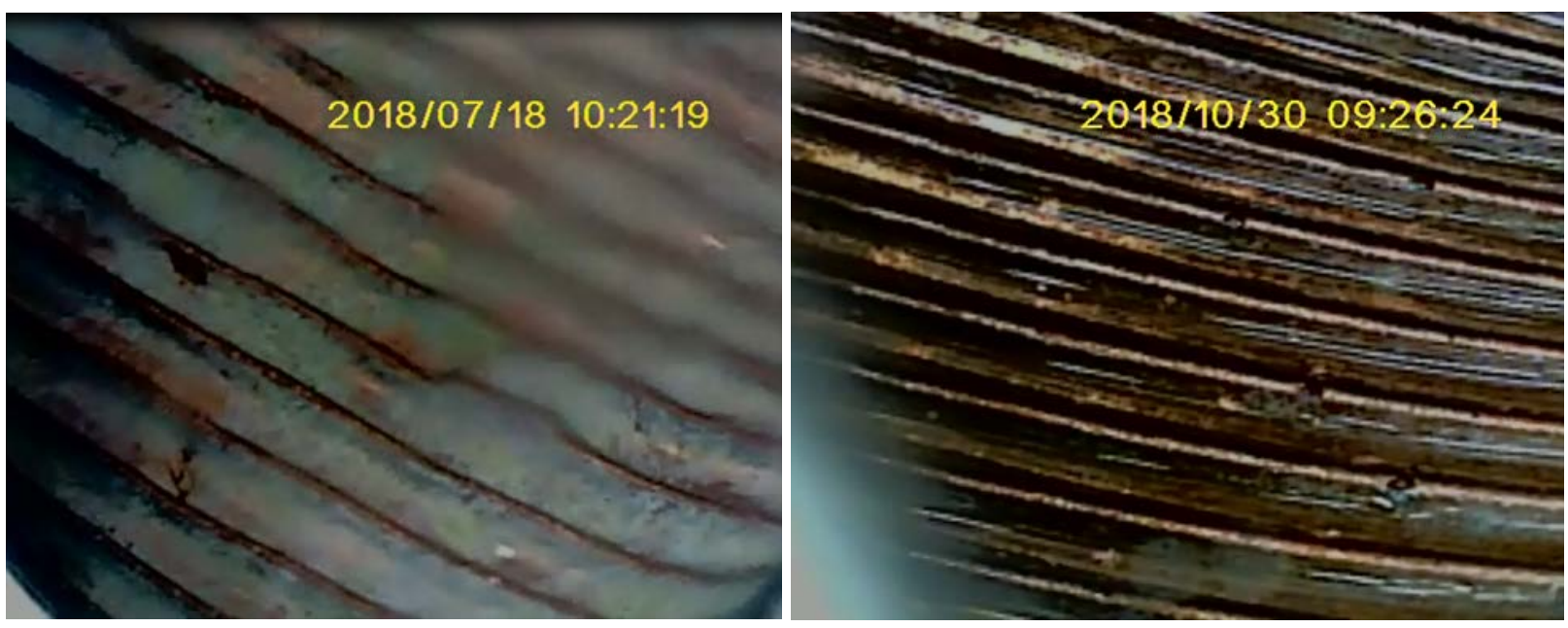

Figure 12. Condenser tube borescope images at the beginning of and after 3 months of DWT-UET operation. Photos by City of LA, Department of General Services 


\section{Summary Findings and Conclusions}

\subsection{Overall Technology Assessment}

The DWT-UET water treatment system was installed in the Los Angeles City Hall East building for evaluation compared to the legacy chemical-based water treatment system. Monitoring of both systems occurred throughout most of 2018. Performance was monitored with existing metering during the baseline system operation period and during the DWT-UET system operation period. Annual performance was determined by comparison of multivariable linear regression models developed for each system.

The DWT-UET system eliminated the need for the use of the scale and corrosion inhibiting chemicals. A small amount of chlorine was added during the first few months of operation as a precautionary measure and was phased out when it was proven that safe conditions were maintained. Removal of calcium and other scale-producing minerals by the DWT-UET system reduced the need for blowdown, which led to an estimated annual water savings of 1.16 million gallons, or $20 \%$ of the makeup water. The biological growth and potential for corrosion were also safely maintained by the DWT-UET system through the automated control system.

Scale buildup in cooling systems can negatively affect the heat transfer and the energy performance of the system. The DWT-UET system actively removes existing scale from the system, which should improve the energy performance, leading to energy savings for the chillers. The potential energy saving is highly dependent on the amount of existing scale in the system and the water quality. Observations in this project were unable to show changes in the chiller plant energy performance. However, longer-term measurements may show savings.

Cost savings were realized through reduced water consumption, reduced sewer discharges, elimination of chemicals, and reduced annual maintenance costs. The total annual cost savings are estimated to be $\$ 34,105$. The reduced scale and tight corrosion control will potentially provide additional savings through extended equipment useful life. The extent of this improvement is unknown and is not included in the cost savings.

The measured performance of the system across the proposed quantitative performance metrics is shown in Table 13. The system performed well and met or was close to meeting the preliminary performance targets. Most significantly, the makeup water savings met the target, the sewer discharge exceeded the target, and the system eliminated the need for added chemicals. The simple payback was 5.5 years, which did not meet the target of 4 years. 
Table 13. Quantitative Performance Metrics

\begin{tabular}{|c|c|c|}
\hline $\begin{array}{l}\text { Technology } \\
\text { Performance } \\
\text { Objective }\end{array}$ & Preliminary Performance Target & Measured Performance \\
\hline Water savings & $>=20 \%$ makeup water savings & $20 \%$ annual makeup water savings \\
\hline Sewer savings & $\begin{array}{l}>=80 \% \text { reduction in sewer } \\
\text { discharges }\end{array}$ & $85 \%$ reduction in sewer discharges \\
\hline Energy savings & $0 \%-5 \%$ & No significant energy savings observed \\
\hline $\begin{array}{l}\text { Maintenance } \\
\text { savings }\end{array}$ & $\begin{array}{l}100 \% \text { reduction in added chemicals } \\
\text { and decrease in maintenance costs, } \\
\text { including costs for mechanical } \\
\text { cleaning and descaling }\end{array}$ & $\begin{array}{l}\text { Eliminated added chemicals } \\
\$ 18,339 \text { maintenance cost savings } \\
\text { Reduced effort for cleaning and } \\
\text { maintaining cooling towers and chillers }\end{array}$ \\
\hline $\begin{array}{l}\text { Safety and handling } \\
\text { savings }\end{array}$ & $\begin{array}{l}\text { Net decrease in cost for handling } \\
\text { chemicals and waste material }\end{array}$ & Eliminated need for added chemicals \\
\hline Equipment life & $\begin{array}{l}\text { Decrease in corrosivity from visual } \\
\text { inspections and water chemistry: } 4-6 \\
\text { on the RSI and }<600 \text { mV ORP }\end{array}$ & $\begin{array}{l}\text { Expected extended life of cooling tower } \\
\text { media } \\
\text { RSI = } 3 \text { to } 4 \text { and LSI = } 2 \text { to } 3 \\
\text { ORP }<200 \mathrm{mV} \\
\text { Too short of period for visual inspection of } \\
\text { corrosion }\end{array}$ \\
\hline Water quality & $\begin{array}{l}\text { Water quality meets site-specific } \\
\text { standards (attributes of interest may } \\
\text { include conductivity, pH, hardness, } \\
\text { alkalinity, silica high range, chloride } \\
\text { anions, salt anions, sulfate anions, } \\
\text { phosphate, copper, iron, and } \\
\text { biological growth) }\end{array}$ & $\begin{array}{l}\text { Water quality meets all site-specific } \\
\text { standards }\end{array}$ \\
\hline Cost-effectiveness & $<4$ years payback & 5.5 years \\
\hline
\end{tabular}

\subsection{Lessons Learned and Recommendations}

The modular nature of the DWT-UET system design scales well from medium-sized cooling towers to large industrial systems. The DWT-UET system works well with most water systems but will provide the most benefit for areas with hard and very hard water $\left(>120\right.$ ppm $\left.\mathrm{CaCO}_{3}\right)$ conditions and for areas with high water and sewer charges. In addition, longer cooling seasons with 8 or more months of cooling system operation will provide a faster payback. The elimination of chemicals and associated service fees can be a significant cost savings contributing to the cost-effectiveness.

Installation of the DWT-UET system is relatively easy but requires space for the reactor skid, new piping to connect the system, $120 \mathrm{~V}$ power for the controller, $120 \mathrm{~V}$ or $220 \mathrm{~V}$ power for the circulation pump, and some control wiring as shown in Figure 4 and Figure 5. A small air compressor or compressed air line is also required. The system startup is simple and requires very little oversight. Operation requires daily walkthroughs and water testing and weekly checks and cleaning. The reactors are inspected quarterly and cleaned as needed. 


\section{References}

American Society of Heating, Refrigerating and Air-Conditioning Engineers. 2014. ASHRAE Guideline 14-2014: Measurement of Energy, Demand, and Water Savings. Atlanta, GA:

ASHRAE.

RStudio. 2019. Boston, MA: https://www.rstudio.com/.

Tomberlin, G., J. Dean, and M. Deru. 2018. Dynamic Water Technologies System for Cooling Tower Applications. Washington, D.C.: General Services Administration.

https://www.gsa.gov/governmentwide-initiatives/sustainability/emerging-buildingtechnologies/about-gsa $\% \mathrm{E} 2 \% 80 \% 99$ s-proving-ground-gpg

U.S. Energy Information Administration. 2012. Commercial Buildings Energy Consumption Survey. Washington, D.C.: Energy Information Administration.

https://www.eia.gov/consumption/commercial/.

U.S. Environmental Protection Agency. 2017. Water Sense Program. Washington, D.C.:

Environmental Protection Administration. https://www.epa.gov/watersense/types-facilities.

WU. 2019. Weather Underground Station KQCT. https://www.wunderground.com. 


\section{Appendix A. Baseline Model Data}

Table A-1. Baseline Model Data

\begin{tabular}{|c|c|c|c|c|c|c|c|}
\hline No. & Date & Day & $\begin{array}{l}\text { Makeup } \\
\text { Water } \\
\text { (gal) }\end{array}$ & $\begin{array}{l}\text { Average } \\
\text { Dry-Bulb } \\
\left.\text { Temp ( }{ }^{\circ} \mathrm{F}\right)\end{array}$ & $\begin{array}{l}\text { Average } \\
\text { Wet-Bulb } \\
\left.\text { Temp ( }{ }^{\circ} \mathrm{F}\right)\end{array}$ & $\begin{array}{l}\text { Cooling Load } \\
\text { (ton-hr) }\end{array}$ & $\begin{array}{c}\text { Conductivity } \\
\text { Setpoint } \\
(\mu \mathrm{S} / \mathrm{cm})\end{array}$ \\
\hline 1 & $04 / 23 / 2018$ & WD & $12,866.6$ & 63.6 & 58.0 & $9,529.3$ & 3500 \\
\hline 2 & $04 / 24 / 2018$ & WD & $11,463.0$ & 61.7 & 55.8 & $8,386.6$ & 3500 \\
\hline 3 & $04 / 25 / 2018$ & WD & $12,347.9$ & 61.5 & 55.3 & $8,198.8$ & 3500 \\
\hline 4 & $04 / 26 / 2018$ & WD & $10,848.0$ & 60.6 & 55.0 & $7,711.7$ & 3500 \\
\hline 5 & $04 / 27 / 2018$ & WD & $9,796.4$ & 60.3 & 54.1 & $7,223.2$ & 3500 \\
\hline 6 & $04 / 28 / 2018$ & WE & $8,587.4$ & 61.2 & 54.4 & $5,858.5$ & 3500 \\
\hline 7 & $04 / 29 / 2018$ & WE & 8,699.0 & 60.9 & 54.1 & $5,567.8$ & 3500 \\
\hline 8 & $04 / 30 / 2018$ & WD & $10,659.4$ & 60.0 & 54.2 & $6,622.2$ & 3500 \\
\hline 9 & $05 / 04 / 2018$ & WD & $21,972.8$ & 71.3 & 58.6 & $10,940.3$ & 3500 \\
\hline 10 & $05 / 05 / 2018$ & WE & $17,174.3$ & 73.6 & 58.6 & $8,507.4$ & 3500 \\
\hline 11 & 05/06/2018 & WE & $14,597.8$ & 68.3 & 58.4 & $7,859.1$ & 3500 \\
\hline 12 & $05 / 08 / 2018$ & WD & $15,934.6$ & 65.9 & 59.2 & $10,171.4$ & 3500 \\
\hline 13 & 05/09/2018 & WD & $15,768.7$ & 65.4 & 59.5 & $10,004.7$ & 3500 \\
\hline 14 & $05 / 12 / 2018$ & WE & 7,113.6 & 59.8 & 55.1 & $5,105.1$ & 3500 \\
\hline 15 & $05 / 13 / 2018$ & WE & $7,627.9$ & 60.7 & 54.9 & $5,180.4$ & 3500 \\
\hline 16 & $05 / 14 / 2018$ & WD & $11,712.9$ & 61.6 & 55.2 & $7,174.6$ & 3500 \\
\hline 17 & $05 / 15 / 2018$ & WD & $10,200.0$ & 61.6 & 55.4 & $6,892.1$ & 3500 \\
\hline 18 & $05 / 16 / 2018$ & WD & $13,310.3$ & 63.3 & 55.6 & $8,216.9$ & 3500 \\
\hline 19 & 05/19/2018 & WE & $8,816.9$ & 61.5 & 56.6 & $5,322.4$ & 2400 \\
\hline 20 & $05 / 20 / 2018$ & WE & $9,147.9$ & 62.6 & 57.1 & $5,524.0$ & 2400 \\
\hline 21 & $05 / 21 / 2018$ & WD & $11,863.5$ & 61.1 & 55.8 & $7,612.4$ & 2400 \\
\hline 22 & $05 / 22 / 2018$ & WD & $10,806.8$ & 61.4 & 55.5 & $7,473.3$ & 2400 \\
\hline 23 & $05 / 23 / 2018$ & WD & $11,188.0$ & 61.6 & 56.4 & $7,442.3$ & 2400 \\
\hline 24 & $05 / 24 / 2018$ & WD & $9,843.1$ & 60.9 & 56.5 & $7,046.6$ & 2500 \\
\hline 25 & $05 / 25 / 2018$ & WD & $10,685.1$ & 62.0 & 55.0 & $7,210.9$ & 2500 \\
\hline 26 & $05 / 26 / 2018$ & WE & $7,654.9$ & 62.2 & 55.4 & $5,641.0$ & 2500 \\
\hline 27 & $05 / 27 / 2018$ & WE & $10,981.2$ & 62.9 & 56.5 & $5,909.8$ & 2500 \\
\hline 28 & $05 / 28 / 2018$ & WD & $15,591.0$ & 63.6 & 58.2 & $8,359.8$ & 2500 \\
\hline 29 & $05 / 29 / 2018$ & WD & $13,143.3$ & 63.2 & 58.9 & $8,199.2$ & 2500 \\
\hline 30 & $05 / 30 / 2018$ & WD & $11,837.2$ & 62.5 & 58.6 & $7,644.6$ & 2500 \\
\hline 31 & $05 / 31 / 2018$ & WD & $13,109.8$ & 64.5 & 57.9 & $8,293.0$ & 2500 \\
\hline 32 & $06 / 01 / 2018$ & WD & $16,090.6$ & 65.1 & 57.9 & $8,858.0$ & 2500 \\
\hline 33 & $06 / 02 / 2018$ & WE & $11,962.1$ & 68.3 & 58.8 & $6,390.0$ & 2500 \\
\hline
\end{tabular}




\begin{tabular}{|c|c|c|c|c|c|c|c|}
\hline No. & Date & Day & $\begin{array}{c}\text { Makeup } \\
\text { Water } \\
\text { (gal) }\end{array}$ & $\begin{array}{l}\text { Average } \\
\text { Dry-Bulb } \\
\left.\text { Temp ( }{ }^{\circ} \mathrm{F}\right)\end{array}$ & $\begin{array}{l}\text { Average } \\
\text { Wet-Bulb } \\
\left.\text { Temp ( }{ }^{\circ} \mathrm{F}\right)\end{array}$ & $\begin{array}{l}\text { Cooling Load } \\
\text { (ton-hr) }\end{array}$ & $\begin{array}{c}\text { Conductivity } \\
\text { Setpoint } \\
(\mu \mathrm{S} / \mathrm{cm})\end{array}$ \\
\hline 34 & $06 / 03 / 2018$ & WE & $14,358.3$ & 68.1 & 61.0 & $7,340.3$ & 2500 \\
\hline 35 & $06 / 04 / 2018$ & WD & $22,560.1$ & 67.5 & 61.1 & $12,712.4$ & 2500 \\
\hline 36 & $06 / 05 / 2018$ & WD & $16,775.6$ & 65.1 & 59.9 & $10,536.8$ & 2500 \\
\hline 37 & $06 / 06 / 2018$ & WD & $14,860.0$ & 64.8 & 58.9 & $9,632.8$ & 2500 \\
\hline 38 & 06/07/2018 & WD & $15,701.3$ & 65.4 & 58.2 & $9,600.0$ & 2500 \\
\hline 39 & $06 / 08 / 2018$ & WD & $20,311.0$ & 69.8 & 59.8 & $11,201.3$ & 2500 \\
\hline 40 & $06 / 09 / 2018$ & WE & $13,286.6$ & 69.9 & 61.2 & $7,555.5$ & 2500 \\
\hline 41 & 06/10/2018 & WE & $14,031.4$ & 69.6 & 60.2 & $7,477.1$ & 2500 \\
\hline 42 & $06 / 11 / 2018$ & WD & $25,777.4$ & 72.0 & 62.0 & $13,817.1$ & 2500 \\
\hline 43 & $06 / 12 / 2018$ & WD & $23,778.3$ & 71.7 & 63.4 & $13,506.9$ & 2500 \\
\hline 44 & $06 / 13 / 2018$ & WD & $22,317.4$ & 70.3 & 63.1 & $12,842.2$ & 2500 \\
\hline 45 & $06 / 14 / 2018$ & WD & $20,589.0$ & 70.1 & 62.8 & $12,828.9$ & 2500 \\
\hline 46 & $06 / 15 / 2018$ & WD & $18,350.9$ & 69.3 & 62.5 & $12,806.3$ & 2500 \\
\hline 47 & $06 / 16 / 2018$ & WE & $9,578.8$ & 64.6 & 57.8 & $6,654.7$ & 2500 \\
\hline 48 & $06 / 17 / 2018$ & WE & $7,698.4$ & 62.9 & 56.0 & $5,833.8$ & 2500 \\
\hline 49 & $06 / 18 / 2018$ & WD & $14,334.9$ & 64.7 & 57.5 & $9,723.8$ & 2500 \\
\hline 50 & $06 / 19 / 2018$ & WD & $15,279.6$ & 65.7 & 59.8 & $10,240.3$ & 2500 \\
\hline 51 & $06 / 20 / 2018$ & WD & $16,735.5$ & 67.6 & 61.9 & $11,212.3$ & 2500 \\
\hline 52 & $06 / 21 / 2018$ & WD & $24,904.6$ & 68.8 & 63.1 & $12,595.7$ & 2500 \\
\hline 53 & $06 / 22 / 2018$ & WD & $23,634.2$ & 68.4 & 63.3 & $12,390.8$ & 2500 \\
\hline 54 & $06 / 23 / 2018$ & WE & $11,013.2$ & 65.3 & 61.1 & $7,082.1$ & 2500 \\
\hline 55 & $06 / 24 / 2018$ & WE & $11,627.5$ & 66.4 & 60.5 & $6,553.3$ & 2500 \\
\hline 56 & $06 / 25 / 2018$ & WD & $21,910.7$ & 68.5 & 61.7 & $12,073.5$ & 2500 \\
\hline 57 & $06 / 26 / 2018$ & WD & $19,589.9$ & 68.0 & 61.8 & $11,428.8$ & 2500 \\
\hline 58 & $06 / 27 / 2018$ & WD & $20,908.8$ & 69.4 & 62.8 & $12,773.8$ & 2500 \\
\hline 59 & $06 / 30 / 2018$ & WE & $12,227.4$ & 68.3 & 61.3 & $6,925.5$ & 2500 \\
\hline 60 & $07 / 01 / 2018$ & WE & $12,425.8$ & 68.9 & 62.2 & $7,485.0$ & 2500 \\
\hline 61 & $07 / 02 / 2018$ & WD & $20,002.8$ & 68.6 & 62.2 & $12,916.8$ & 2500 \\
\hline 62 & $07 / 03 / 2018$ & WD & $19,089.9$ & 68.8 & 62.1 & $12,330.8$ & 2500 \\
\hline 63 & $07 / 04 / 2018$ & WD & $16,115.3$ & 69.6 & 62.2 & $10,011.6$ & 2500 \\
\hline 64 & $07 / 05 / 2018$ & WD & $20,743.5$ & 74.5 & 64.8 & $14,096.2$ & 2500 \\
\hline 65 & 07/06/2018 & WD & $31,777.5$ & 90.6 & 66.8 & $17,971.9$ & 2500 \\
\hline 66 & 07/07/2018 & WE & $21,222.5$ & 86.4 & 68.4 & $10,684.2$ & 2500 \\
\hline
\end{tabular}




\section{Appendix B. Validation Performance Data}

Table B-1. DWT-UET Model Data

\begin{tabular}{|c|c|c|c|c|c|c|}
\hline No. & Date & Day & $\begin{array}{l}\text { Makeup } \\
\text { Water } \\
\text { (gal) }\end{array}$ & $\begin{array}{l}\text { Average Dry-Bulb } \\
\text { Temperature }\left({ }^{\circ} \mathrm{F}\right)\end{array}$ & $\begin{array}{l}\text { Average Wet-Bulb } \\
\text { Temperature }\left({ }^{\circ} \mathrm{F}\right)\end{array}$ & $\begin{array}{l}\text { Cooling Load } \\
\text { (ton-hr) }\end{array}$ \\
\hline 1 & $07 / 27 / 2018$ & WD & $28,130.7$ & 76.7 & 69.1 & $17,946.9$ \\
\hline 2 & $07 / 28 / 2018$ & WE & $18,968.3$ & 74.8 & 68.0 & $11,473.0$ \\
\hline 3 & $07 / 29 / 2018$ & WE & $24,207.2$ & 77.9 & 68.2 & $15,124.2$ \\
\hline 4 & $07 / 30 / 2018$ & WD & $29,119.4$ & 78.2 & 67.6 & $18,560.3$ \\
\hline 5 & $07 / 31 / 2018$ & WD & $27,581.0$ & 78.4 & 67.0 & $17,025.8$ \\
\hline 6 & $08 / 01 / 2018$ & WD & $28,540.0$ & 78.4 & 67.0 & $17,596.8$ \\
\hline 7 & 08/02/2018 & WD & $28,504.0$ & 77.6 & 67.2 & $18,244.3$ \\
\hline 8 & 08/03/2018 & WD & $29,227.0$ & 78.2 & 67.5 & $17,938.7$ \\
\hline 9 & $08 / 04 / 2018$ & WE & $22,485.0$ & 76.5 & 67.7 & $14,132.5$ \\
\hline 10 & 08/05/2018 & WE & $23,087.0$ & 76.5 & 67.9 & $13,692.4$ \\
\hline 11 & 08/06/2018 & WD & $32,349.0$ & 79.7 & 68.7 & $18,202.8$ \\
\hline 12 & $08 / 07 / 2018$ & WD & $33,446.0$ & 81.9 & 68.8 & $18,658.8$ \\
\hline 13 & 08/08/2018 & WD & $33,414.0$ & 82.1 & 67.6 & $18,468.9$ \\
\hline 14 & 08/09/2018 & WD & $31,871.0$ & 81.4 & 67.9 & $18,460.4$ \\
\hline 15 & 08/10/2018 & WD & $34,676.0$ & 81.1 & 64.1 & $17,445.3$ \\
\hline 16 & $08 / 11 / 2018$ & WE & $21,395.0$ & 78.2 & 67.6 & $13,735.7$ \\
\hline 17 & $08 / 12 / 2018$ & WE & $19,870.0$ & 76.0 & 67.8 & $13,715.5$ \\
\hline 18 & $08 / 13 / 2018$ & WD & $22,841.0$ & 74.4 & 65.5 & $17,313.8$ \\
\hline 19 & $08 / 14 / 2018$ & WD & $22,260.0$ & 73.7 & 65.3 & $16,889.8$ \\
\hline 20 & $08 / 15 / 2018$ & WD & $24,224.0$ & 74.4 & 67.2 & $17,791.7$ \\
\hline 21 & $08 / 16 / 2018$ & WD & $24,826.0$ & 75.5 & 68.8 & $18,597.7$ \\
\hline 22 & 08/17/2018 & WD & $26,396.0$ & 76.1 & 69.6 & $19,322.0$ \\
\hline 23 & 08/18/2018 & WE & $18,953.0$ & 74.7 & 68.0 & $13,766.1$ \\
\hline 24 & $08 / 19 / 2018$ & WE & $19,383.0$ & 74.8 & 68.3 & $12,884.6$ \\
\hline 25 & $08 / 20 / 2018$ & WD & $24,928.0$ & 74.7 & 68.1 & $17,518.0$ \\
\hline 26 & $08 / 21 / 2018$ & WD & $23,347.0$ & 74.5 & 67.9 & $16,865.1$ \\
\hline 27 & $08 / 22 / 2018$ & WD & $23,334.0$ & 74.5 & 67.1 & $16,568.8$ \\
\hline 28 & $08 / 23 / 2018$ & WD & $22,645.0$ & 73.1 & 66.2 & $16,584.6$ \\
\hline 29 & $08 / 24 / 2018$ & WD & $21,085.0$ & 71.9 & 64.9 & $15,173.6$ \\
\hline 30 & $08 / 25 / 2018$ & WE & $16,506.0$ & 70.9 & 64.7 & $12,079.3$ \\
\hline 31 & 08/26/2018 & WE & $19,356.0$ & 70.7 & 64.3 & $12,811.0$ \\
\hline 32 & $08 / 27 / 2018$ & WD & $19,198.0$ & 69.9 & 63.6 & $14,407.0$ \\
\hline 33 & $08 / 28 / 2018$ & WD & $18,875.0$ & 70.2 & 63.8 & $14,331.3$ \\
\hline
\end{tabular}




\begin{tabular}{|c|c|c|c|c|c|c|}
\hline No. & Date & Day & $\begin{array}{c}\text { Makeup } \\
\text { Water } \\
\text { (gal) }\end{array}$ & $\begin{array}{l}\text { Average Dry-Bulb } \\
\text { Temperature }\left({ }^{\circ} \mathrm{F}\right)\end{array}$ & $\begin{array}{l}\text { Average Wet-Bulb } \\
\text { Temperature }\left({ }^{\circ} \mathrm{F}\right)\end{array}$ & $\begin{array}{l}\text { Cooling Load } \\
\text { (ton-hr) }\end{array}$ \\
\hline 34 & $08 / 29 / 2018$ & WD & $21,391.0$ & 73.0 & 64.2 & $15,446.4$ \\
\hline 35 & 08/30/2018 & WD & $21,000.0$ & 73.3 & 63.1 & $15,363.3$ \\
\hline 36 & 08/31/2018 & WD & $21,252.0$ & 72.9 & 64.0 & $15,201.6$ \\
\hline 37 & 09/01/2018 & WE & $15,800.0$ & 71.1 & 64.7 & $11,402.9$ \\
\hline 38 & 09/02/2018 & WE & $15,967.0$ & 70.4 & 64.1 & $9,931.4$ \\
\hline 39 & 09/03/2018 & WD & $19,962.0$ & 70.4 & 64.6 & $12,724.3$ \\
\hline 40 & 09/04/2018 & WD & $19,103.0$ & 69.6 & 64.4 & $13,746.0$ \\
\hline 41 & 09/05/2018 & WD & $17,269.0$ & 68.5 & 63.8 & $12,647.8$ \\
\hline 42 & 09/06/2018 & WD & $19,358.0$ & 68.7 & 63.7 & $12,771.8$ \\
\hline 43 & 09/07/2018 & WD & $22,517.0$ & 70.8 & 64.8 & $14,583.5$ \\
\hline 44 & 09/08/2018 & WE & $21,457.0$ & 73.2 & 66.4 & $13,404.9$ \\
\hline 45 & 09/09/2018 & WE & $21,571.0$ & 73.1 & 66.4 & $13,348.0$ \\
\hline 46 & 09/10/2018 & WD & $21,541.0$ & 72.0 & 65.6 & $15,634.0$ \\
\hline 47 & 09/11/2018 & WD & $19,519.0$ & 71.1 & 64.1 & $14,556.1$ \\
\hline 48 & 09/12/2018 & WD & $19,031.0$ & 70.4 & 63.6 & $14,501.4$ \\
\hline 49 & 09/13/2018 & WD & $19,857.0$ & 72.5 & 64.1 & $14,737.8$ \\
\hline 50 & 09/14/2018 & WD & $21,723.0$ & 76.3 & 60.5 & $14,671.2$ \\
\hline 51 & 09/15/2018 & WE & $17,531.0$ & 72.8 & 61.7 & $12,204.0$ \\
\hline 52 & 09/16/2018 & WE & $18,653.0$ & 73.2 & 60.5 & $10,377.6$ \\
\hline 53 & 09/17/2018 & WD & $21,115.0$ & 72.3 & 59.4 & $13,384.0$ \\
\hline 54 & 09/18/2018 & WD & $18,274.0$ & 70.3 & 59.7 & $12,742.2$ \\
\hline 55 & 09/19/2018 & WD & $18,246.0$ & 68.7 & 61.1 & $12,783.5$ \\
\hline 56 & 09/20/2018 & WD & $19,294.0$ & 69.9 & 63.2 & $13,970.2$ \\
\hline 57 & 09/21/2018 & WD & $19,512.0$ & 70.4 & 63.8 & $14,474.4$ \\
\hline 58 & 09/22/2018 & WE & $15,126.0$ & 70.3 & 63.7 & $10,845.5$ \\
\hline 59 & 09/23/2018 & WE & $15,167.0$ & 69.6 & 62.8 & $9,804.2$ \\
\hline 60 & 09/24/2018 & WD & $18,073.0$ & 67.4 & 61.4 & $13,294.8$ \\
\hline 61 & 09/25/2018 & WD & $14,606.0$ & 65.9 & 60.9 & $12,108.2$ \\
\hline 62 & 09/26/2018 & WD & $18,708.0$ & 68.3 & 62.9 & $13,944.2$ \\
\hline 63 & 09/27/2018 & WD & $19,521.0$ & 70.2 & 64.0 & $14,449.8$ \\
\hline 64 & 09/28/2018 & WD & $18,799.0$ & 69.3 & 64.0 & $14,889.3$ \\
\hline 65 & 09/29/2018 & WE & $14,164.0$ & 68.8 & 61.6 & $9,817.7$ \\
\hline 66 & 09/30/2018 & WE & $14,294.0$ & 70.6 & 62.1 & $9,461.1$ \\
\hline 67 & $10 / 01 / 2018$ & WD & $23,234.0$ & 76.8 & 63.8 & $15,052.4$ \\
\hline 68 & $10 / 02 / 2018$ & WD & $20,434.0$ & 72.6 & 62.8 & $14,318.1$ \\
\hline 69 & $10 / 03 / 2018$ & WD & $17,820.0$ & 70.2 & 63.2 & $12,911.1$ \\
\hline
\end{tabular}




\begin{tabular}{|c|c|c|c|c|c|c|}
\hline No. & Date & Day & $\begin{array}{c}\text { Makeup } \\
\text { Water } \\
\text { (gal) }\end{array}$ & $\begin{array}{c}\text { Average Dry-Bulb } \\
\text { Temperature }\left({ }^{\circ} \mathbf{F}\right)\end{array}$ & $\begin{array}{c}\text { Average Wet-Bulb } \\
\left.\text { Temperature ( }{ }^{\circ} \mathbf{F}\right)\end{array}$ & $\begin{array}{c}\text { Cooling Load } \\
\text { (ton-hr) }\end{array}$ \\
\hline 70 & $10 / 04 / 2018$ & WD & $17,769.0$ & 68.5 & 63.0 & $13,230.7$ \\
\hline 71 & $10 / 05 / 2018$ & WD & $16,829.0$ & 67.9 & 62.2 & $12,461.3$ \\
\hline 72 & $10 / 06 / 2018$ & WE & $12,839.0$ & 67.4 & 61.9 & $9,695.4$ \\
\hline 73 & $10 / 07 / 2018$ & WE & $11,284.0$ & 67.3 & 60.5 & $7,163.6$ \\
\hline 74 & $10 / 08 / 2018$ & WD & $16,454.0$ & 67.0 & 60.3 & $11,940.9$ \\
\hline 75 & $10 / 09 / 2018$ & WD & $14,521.0$ & 66.3 & 59.4 & $11,343.5$ \\
\hline 76 & $10 / 10 / 2018$ & WD & $13,133.0$ & 65.0 & 57.4 & $10,516.8$ \\
\hline 77 & $10 / 11 / 2018$ & WD & $13,713.0$ & 65.6 & 55.6 & $10,269.3$ \\
\hline 78 & $10 / 12 / 2018$ & WD & $14,431.0$ & 67.2 & 58.3 & $11,069.1$ \\
\hline 79 & $10 / 13 / 2018$ & WE & $5,472.0$ & 64.4 & 59.9 & $6,050.4$ \\
\hline
\end{tabular}




\section{Appendix C. Acclimation Period Data}

Table C-1. DWT-UET System Acclimation Period Data

\begin{tabular}{|c|c|c|c|c|c|}
\hline No. & Date & Day & $\begin{array}{c}\text { Average Dry-Bulb } \\
\left.\text { Temperature ( }{ }^{\circ} \mathbf{F}\right)\end{array}$ & $\begin{array}{c}\text { Average Wet-Bulb } \\
\text { Temperature }\left({ }^{\circ} \mathbf{F}\right)\end{array}$ & $\begin{array}{c}\text { Cooling Load } \\
\text { (ton-hr) }\end{array}$ \\
\hline 1 & $7 / 8 / 2018$ & WE & 85.5 & 66.5 & $10,961.5$ \\
\hline 2 & $7 / 9 / 2018$ & WD & 82.6 & 68.0 & $19,878.1$ \\
\hline 3 & $7 / 10 / 2018$ & WD & 78.9 & 68.2 & $19,659.4$ \\
\hline 4 & $7 / 11 / 2018$ & WD & 78.5 & 67.4 & $19,056.9$ \\
\hline 5 & $7 / 12 / 2018$ & WD & 76.8 & 68.0 & $17,826.5$ \\
\hline 6 & $7 / 13 / 2018$ & WD & 74.4 & 67.0 & $16,885.3$ \\
\hline 7 & $7 / 14 / 2018$ & WE & 74.7 & 66.7 & $11,752.0$ \\
\hline 8 & $7 / 15 / 2018$ & WE & 75.8 & 67.8 & $10,577.8$ \\
\hline 9 & $7 / 16 / 2018$ & WD & 74.4 & 67.3 & $17,397.4$ \\
\hline 10 & $7 / 17 / 2018$ & WD & 72.9 & 66.5 & $16,079.2$ \\
\hline 11 & $7 / 18 / 2018$ & WD & 73.4 & 67.1 & $16,054.3$ \\
\hline 12 & $7 / 19 / 2018$ & WD & 75.2 & 67.5 & $16,592.9$ \\
\hline 13 & $7 / 24 / 2018$ & WD & 80.6 & 68.7 & $18,051.7$ \\
\hline 14 & $7 / 25 / 2018$ & WD & 78.7 & 70.3 & $18,074.1$ \\
\hline 15 & $7 / 26 / 2018$ & WD & 76.1 & 69.6 & $17,439.8$ \\
\hline
\end{tabular}




\section{Appendix D. Uncertainty Calculations}

The American Society of Heating, Refrigerating, and Air-Conditioning Engineers (ASHRAE) Guideline 14 (2014) defines the minimum requirements and determination of uncertainty for measurement and verification of energy and water projects. In general, the uncertainty for a project with regression analysis is determined by Eq. $\left(U=\frac{t}{F} \sqrt{U_{\text {model }}^{2}+U_{S}^{2}+R E_{\text {instrument }}^{2}}\right.$

(4), which simplifies to Eq. $\left(U=\frac{t}{F} \times 1.26 \times C V(R M S E) \times \sqrt{\frac{n+2}{n \times m}} \quad\right.$ (5) when no sampling is done and the savings are not determined by comparison to measured data or when the instrument error is very small. The savings for this project were estimated by comparison of two linear regression models applied over the same period and the uncertainty can be estimated by Eq. $\left(\mathrm{U}=\frac{\mathrm{t}}{\mathrm{F}} \sqrt{\mathrm{U}_{\text {baseline }}^{2}+\mathrm{U}_{\mathrm{DWT}}^{2}} \quad\right.$ (6), where the uncertainty for each model is determined by Eq. $\left(U_{\text {model }}=1.26 \times \mathrm{CV}(\mathrm{RMSE}) \times \sqrt{\frac{\mathrm{n}+2}{\mathrm{n} \times \mathrm{m}}}\right.$ (7). Note that errors introduced through the measurement of independent variables is included in the coefficient of variation assuming there is no bias in the reported data (ASHRAE 2014).

$$
\begin{aligned}
& U=\frac{t}{F} \sqrt{U_{\text {model }}^{2}+U_{S}^{2}+R E_{\text {instrument }}^{2}} \\
& U=\frac{t}{F} \times 1.26 \times C V(R M S E) \times \sqrt{\frac{n+2}{n \times m}} \\
& U=\frac{t}{F} \sqrt{U_{\text {baseline }}^{2}+U_{D W T}^{2}} \\
& U_{\text {model }}=1.26 \times C V(R M S E) \times \sqrt{\frac{n+2}{n \times m}} \\
& C V(R M S E)=\frac{\sqrt{\frac{\sum\left(y_{i}-\hat{y}_{i}\right)^{2}}{(n-p)}}}{\bar{y}} \\
& N M B E=\frac{\sum_{i=1}^{n}\left(y_{i}-\hat{y}_{i}\right)}{(n-p) \cdot \bar{y}}
\end{aligned}
$$

Where:

$\begin{array}{ll}\text { CV(RMSE) } & \text { coefficient of variance of the root-mean-square error } \\ \mathrm{F} & \text { percentage of baseline water savings } \\ \mathrm{m} & \text { number of periods (days) used for model application } \\ \mathrm{n} & \text { number of periods (days) used for model development } \\ \mathrm{NMBE} & \text { normalized mean biased error } \\ \mathrm{p} & \text { number of parameters in the regression model } \\ \mathrm{RE} & \text { relative error in an instrument measurement }\end{array}$


t-statistic ( 1.65 for $90 \%$ confidence and $(n-p)>>25)$

relative uncertainty in reported savings

uncertainty created by sampling

measured dependent variable

arithmetic mean of the sample of $n$ observations

regression model prediction of $y$ 